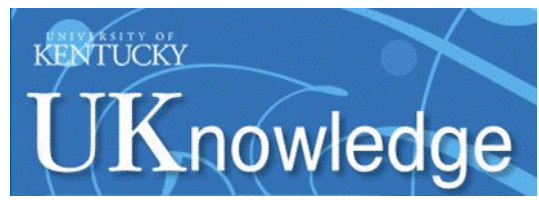

University of Kentucky

UKnowledge

\title{
Peripheral Administration of the Soluble TNF Inhibitor XPro1595 Modifies Brain Immune Cell Profiles, Decreases Beta-Amyloid Plaque Load, and Rescues Impaired Long-Term Potentiation in 5xFAD Mice
}

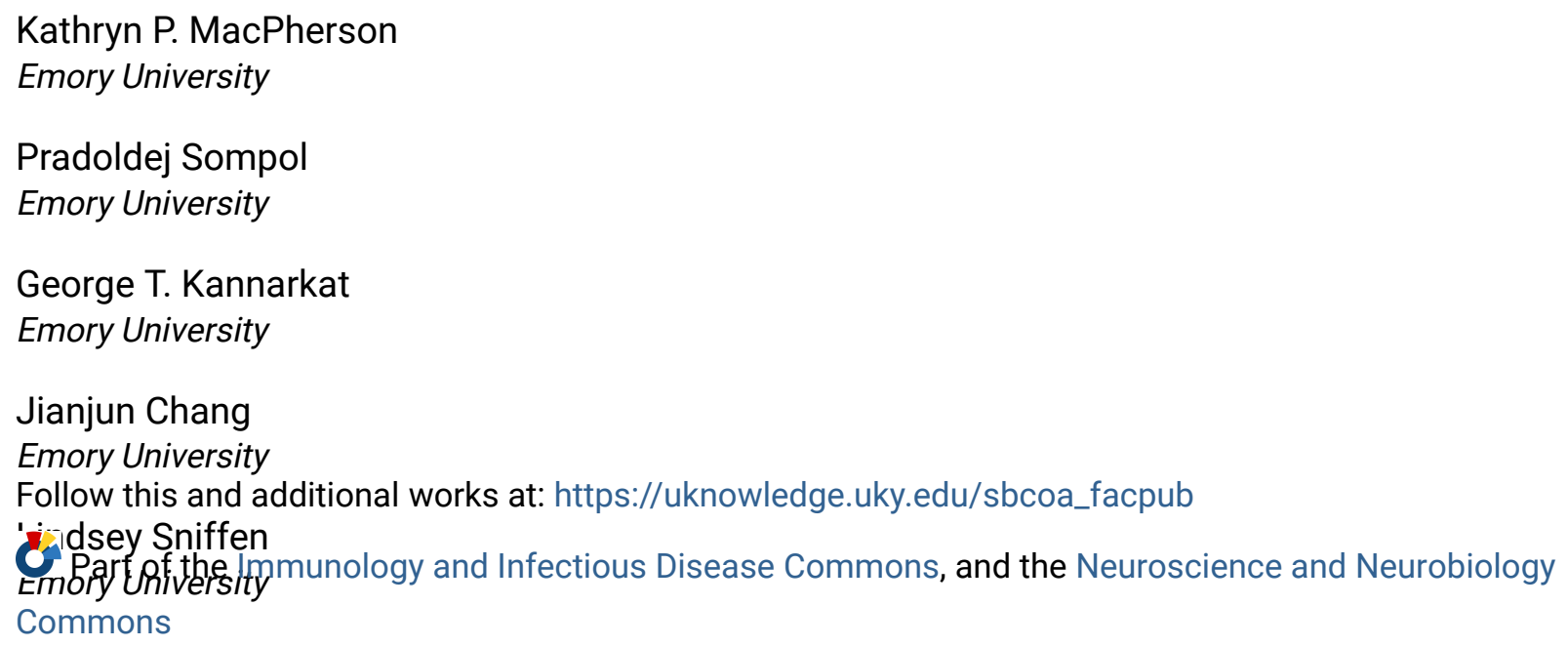

Right click to open a feedback form in a new tab to let us know how this document benefits you. See next page for additional authors

\section{Repository Citation}

MacPherson, Kathryn P.; Sompol, Pradoldej; Kannarkat, George T.; Chang, Jianjun; Sniffen, Lindsey; Wildner, Mary E.; Norris, Christopher M.; and Tansey, Malú G., "Peripheral Administration of the Soluble TNF Inhibitor XPro1595 Modifies Brain Immune Cell Profiles, Decreases Beta-Amyloid Plaque Load, and Rescues Impaired Long-Term Potentiation in 5xFAD Mice" (2017). Sanders-Brown Center on Aging Faculty Publications. 125.

https://uknowledge.uky.edu/sbcoa_facpub/125 


\section{Peripheral Administration of the Soluble TNF Inhibitor XPro1595 Modifies Brain Immune Cell Profiles, Decreases Beta-Amyloid Plaque Load, and Rescues Impaired Long-Term Potentiation in 5xFAD Mice}

Digital Object Identifier (DOI)

https://doi.org/10.1016/j.nbd.2017.02.010

Notes/Citation Information

Published in Neurobiology of Disease, v. 102, p. 81-95.

(C) 2017 Elsevier Inc. All rights reserved.

This manuscript version is made available under the CC-BY-NC-ND 4.0 license https://creativecommons.org/licenses/by-nc-nd/4.0/.

The document available for download is the author's post-peer-review final draft of the article.

Authors

Kathryn P. MacPherson, Pradoldej Sompol, George T. Kannarkat, Jianjun Chang, Lindsey Sniffen, Mary E. Wildner, Christopher M. Norris, and Malú G. Tansey 


\title{
Peripheral administration of the soluble TNF inhibitor XPro1595 modifies brain immune cell profiles, decreases beta-amyloid plaque load, and rescues impaired long-term potentiation in 5xFAD mice
}

\author{
Kathryn P. MacPherson ${ }^{\mathrm{a}}$, Pradoldej Sompol ${ }^{\mathrm{b}}$, George T. Kannarkat ${ }^{\mathrm{a}}$, Jianjun Chang ${ }^{\mathrm{a}}$, \\ Lindsey Sniffen ${ }^{a}$, Mary E. Wildner ${ }^{a}$, Christopher M. Norris ${ }^{b}$, and Malú G. Tansey ${ }^{a},{ }^{*}$ \\ aEmory University School of Medicine, 30322, United States \\ bSanders-Brown Center on Aging, University of Kentucky College of Medicine, Lexington, KY \\ 40536, United States
}

\begin{abstract}
Clinical and animal model studies have implicated inflammation and peripheral immune cell responses in the pathophysiology of Alzheimer's disease (AD). Peripheral immune cells including $T$ cells circulate in the cerebrospinal fluid (CSF) of healthy adults and are found in the brains of $\mathrm{AD}$ patients and $\mathrm{AD}$ rodent models. Blocking entry of peripheral macrophages into the CNS was reported to increase amyloid burden in an AD mouse model. To assess inflammation in the 5xFAD (Tg) mouse model, we first quantified central and immune cell profiles in the deep cervical lymph nodes and spleen. In the brains of $\mathrm{Tg}$ mice, activated ( $\mathrm{MHCII}^{+}, \mathrm{CD} 45^{\text {high }}$, and $\mathrm{Ly} 6 \mathrm{C}^{\text {high }}$ ) myeloidderived $\mathrm{CD} 11 \mathrm{~b}^{+}$immune cells are decreased while $\mathrm{CD}^{+} \mathrm{T}$ cells are increased as a function of age relative to non-Tg mice. These immunological changes along with evidence of increased mRNA levels for several cytokines suggest that immune regulation and trafficking patterns are altered in Tg mice. Levels of soluble Tumor Necrosis Factor (sTNF) modulate blood-brain barrier (BBB) permeability and are increased in CSF and brain parenchyma post-mortem in AD subjects and $\mathrm{Tg}$ mice. We report here that in vivo peripheral administration of XPro1595, a novel biologic that sequesters sTNF into inactive heterotrimers, reduced the age-dependent increase in activated immune cells in $\mathrm{Tg}$ mice, while decreasing the overall number of $\mathrm{CD} 4^{+} \mathrm{T}$ cells. In addition, XPro1595 treatment in vivo rescued impaired long-term potentiation (LTP) measured in brain slices in association with decreased A $\beta$ plaques in the subiculum. Selective targeting of sTNF may modulate brain immune cell infiltration, and prevent or delay neuronal dysfunction in AD.
\end{abstract}

Significance statement-Immune cells and cytokines perform specialized functions inside and outside the brain to maintain optimal brain health; but the extent to which their activities change in response to neuronal dysfunction and degeneration is not well understood. Our findings indicate

\footnotetext{
*Corresponding author at: Emory University School of Medicine, 605L Whitehead Biomedical Res. Bldg., 615 Michael Street, Atlanta, GA 30322-3110, United States. malu.tansey@emory.edu (M.G. Tansey).

Available online on ScienceDirect (www.sciencedirect.com).

Conflict of Interest: Malú G. Tansey is a former Xencor Inc. employee and co-inventor on patents covering the dominant negative TNF variants (XPro1595). She does not hold significant financial stake in the company and is not a consultant.

Supplementary data to this article can be found online at http://dx.doi.org/10.1016/j.nbd.2017.02.010.
} 
that neutralization of sTNF reduced the age-dependent increase in activated immune cells in $\mathrm{Tg}$ mice, while decreasing the overall number of $\mathrm{CD} 4^{+}$Tcells. In addition, impaired long-term potentiation (LTP) was rescued by XPro1595 in association with decreased hippocampal A $\beta$ plaques. Selective targeting of sTNF holds translational potential to modulate brain immune cell infiltration, dampen neuroinflammation, and prevent or delay neuronal dysfunction in AD.

\section{Keywords}

Neuroinflammation; Alzheimer's disease; Immune cell trafficking; T cells; Macrophage; MHCII; Soluble TNF; Long-term potentiation; XPro1595

\section{Introduction}

Inflammation as a hallmark of Alzheimer's disease (AD) is well established. However, the mechanisms by which the peripheral immune system contributes to the etiology or progression of $\mathrm{AD}$ are not yet elucidated. The pro-inflammatory response of brain-resident immune cells to AD pathophysiology leads to increased local production of cytokines and chemokines, and recruitment of peripheral immune cells (Akiyama et al., 2000; Heneka et al., 2015). The chemoattractant CCL2/MCP-1, plays an important role in recruitment of phagocytic macrophages to the inflamed CNS (Hickman and El Khoury, 2010), and is upregulated in CSF, but not plasma, of MCI and early stage AD patients (Brosseron et al., 2014). These observations suggest peripheral immune cells respond to signals generated in the CNS and traffic across the blood brain barrier (BBB) to play an important role in early AD. T cells are also found in increasing frequency in postmortem brain of aged individuals and patients with AD (Togo et al., 2002). Recently identified lymphatic vessels in the rodent brain regulate neuroimmune responses by connecting to deep cervical lymph nodes (DCLNs) where they drain antigens from the brain parenchyma (Ransohoff and Engelhardt, 2012; Laman and Weller, 2013; Aspelund et al., 2015; Louveau et al., 2015). The extent to which alterations in immune cell trafficking to the brain occur during the course of AD and whether these are beneficial or maladaptive remains unknown.

At the pinnacle of inflammatory cascades, elevations in TNF are associated not only with induction of the inflammatory response but also with chronic inflammation (MacEwan, 2002; Steinman, 2013). TNF exists in two functional forms: soluble TNF (sTNF) and transmembrane TNF (tmTNF), each with distinct functional bioactivities. sTNF signaling, primarily via TNFR1, results in pro-inflammatory actions while tmTNF signaling, primarily via TNFR2 results in pro-survival signaling and plays an important role in immune system development (McCoy and Tansey, 2008). TNF elevations are reported in AD patient plasma, and an acute increase in serum TNF, as well as higher baseline TNF level, has been associated with greater cognitive decline in elderly populations (Holmes et al., 2009; Swardfager et al., 2010). Results from non-selective TNF blockade in pre-clinical animal models of AD-like pathology call into question the validity of the therapeutic benefit of targeting TNF in AD (Montgomery et al., 2011); however studies specifically targeting sTNF/TNFR1 axis in the CNS are promising (McAlpine et al., 2009). Neuronal ablation of TNFR2, but not TNFR1, increased extracellular A $\beta$ (Montgomery et al., 2013), a hallmark of AD pathology, while ablation of TNFR1 increased Iba1 (microglial) reactivity in the 
hippocampus of 12-month old 3xTg-AD mice (Montgomery et al., 2013), a potentially beneficial response as microglia have a complex role in brain health and disease (Mandrekar-Colucci and Landreth, 2010). Together, these data provide rationale for the specific targeting of sTNF while sparing tmTNF/TNFR2 signaling. Moreover, loss of BBB integrity establishes an environment susceptible to dysregulated interactions with the peripheral immune system. TNF downregulates the BBB phenotype in human brain microvascular endothelial cells at $1 \mathrm{ng} / \mathrm{mL}$ TNF (Rochfort et al., 2014). While plasma and CSF TNF levels in AD patients are typically 10 fold lower than this, the permeability of the $\mathrm{BBB}$ increases as a function of age and these sTNF levels may be sufficient for further BBB disruption in subjects with MCI, promoting faster conversion to AD (Swardfager et al., 2010; Montagne et al., 2015).

Here, we measure populations of peripheral immune cells found in the CNS of 5xFAD (Tg) mice and assess the role of STNF in recruiting these populations to the brain. We investigated whether inhibition of sTNF, with XPro1595 (Steed et al., 2003; McCoy et al., 2006; Brambilla et al., 2011) would mitigate the AD-like pathology found in Tg mice and evaluated the extent to which these effects occur in association with alterations in central and peripheral immune cell population profiles. Our results showed that neutralization of sTNF reduces proinflammatory immune cell markers and gene expression, and rescues impaired LTP within the Tg brain.

\section{Methods}

\subsection{Animals}

The 5xFAD ( Tg) mouse model displays key pathological hallmarks of AD including synaptic dysfunction, plaque accumulations, and neuronal degeneration (Oakley et al., 2006). While amyloid deposition begins early in this model, around 2 months, spatial working memory deficits in Y-maze are not detected until 4-5 months of age (Oakley et al., 2006). Our own group has not found significant deficits in 8-arm radial water maze until 810 months (unpublished observations). Female 5xFAD mice, on a congenic C57BL/6J background, were used for all flow cytometry, XPro1595, and electrophysiology experiments to assess the role of STNF and trafficking immune cell populations in AD-like pathology. Female mice were used because they show accelerated AD-like pathology when compared to male 5xFAD mice (Oakley et al., 2006). For all XPro1595 studies mice were randomly assigned to treatment group based on genotype, and investigators involved in quantification of outcome measures were blinded to genotype and treatment history. For measurements of cytokines in CSF by multiplexed immunoassay and inflammatory mRNA analysis by qPCR, we used both male and female mice at 2-, 4-, and 6-months of age to assess baseline level of inflammation in the periphery and within the brain, Table 1. Specifics on age and group size are detailed in each specific methods section. Tg mice, generously provided by Vassar lab, were co-housed in a vivarium at Emory University, or University of Kentucky for electrophysiology studies, with ad libitum access to food and water on a $12 \mathrm{~h} \mathrm{light/dark} \mathrm{cycle.} \mathrm{All} \mathrm{experimental} \mathrm{procedures} \mathrm{were} \mathrm{approved} \mathrm{by} \mathrm{the}$ Institutional Animal Care and Use Committee of Emory University or University of 
Kentucky and comply with the National Institutes of Health guide for the care and use of Laboratory animals.

\subsection{Multiplexed immunoassays}

Serum and CSF samples were analyzed for cytokines and chemokines that play key roles in pro-inflammatory and anti-inflammatory pathways (IFN- $\gamma$, IL-1 $\beta$, IL-6, IL-10, IL-12p70, $\mathrm{mKC} / \mathrm{CXCL1}$, and TNF) using a V-PLEX multiplexed immunoassay per the manufacturer's instructions (Meso Scale Discovery, Gaithersburg, MD). XPro1595 levels in serum and brain were measured using an anti-human TNF ultrasensitive (Cat \# K151BHC-1) singleplex immunoassay and quantified using the Meso Scale Discovery SECTOR Imager 2400-A (Meso Scale Diagnostics, LLC, Rockville, MD). To measure XPro1595, the supplied human TNF protein used to generate a calibrator/standard protein was replaced by the XPro1595 protein, which increases the sensitivity of the assay substantially. Signals from the linear standard curve range from 3000 (at 0 XPro1595) to 1 million counts (at $250 \mathrm{ng} / \mathrm{mL}$ ). All samples were assayed in duplicate by an experimentalist blinded to treatment history. The data were analyzed and converted to $\mathrm{pg} / \mathrm{mL}$ values using the Meso Scale Discovery integrated data analysis software. Mice used: 2 months of age Tg: 4 male and 3 female samples pooled $-30 \mu \mathrm{L}$ total; non-Tg: 1 male and 7 female samples pooled $-20 \mu \mathrm{L}$ total; 4 months of age Tg: 2 male and 3 female samples pooled $-20 \mu \mathrm{L}$ total; non-Tg: 5 male and 3 female samples pooled $-50 \mu \mathrm{L}$ total; 6 months of age Tg: 5 male and 3 female samples pooled $-30 \mu \mathrm{L}$ total; non-Tg: 3 male and 2 female samples pooled $-40 \mu \mathrm{L}$ total. Samples were run in replicates of $10 \mu \mathrm{L}$. Samples were pooled for analysis of CSF cytokines and chemokines due to the very low volume yield per animal.

\subsection{Brain dissociation for immune cell isolation}

5xFAD mice were anesthetized with isoflurane and whole brain, deep cervical lymph nodes, and spleen were removed. Rapid removal of the brain ensured high immune cell yield and viability needed to run two multi-channel flow panels on the harvested immune cells. In pilot studies, we compared the yield, viability, and brain immune subset frequencies between perfused and non-perfused mice and confirmed that this method of harvest did not result in contamination from blood vessels as there were no differences across the non-brain tissues (spleen and deep cervical lymph nodes) in $\mathrm{CD}^{+}$and $\mathrm{CD} 8^{+} \mathrm{T}$ cell subsets, or in the number of viable cells (data not shown). More importantly, we found no significant differences in the frequency of total $\mathrm{CD}^{+} \mathrm{T}$ cell or within the $\mathrm{CD} 4^{+}$and $\mathrm{CD} 8^{+} \mathrm{T}$ cell subset populations in the brains of non-perfused as compared to perfused mice. Given that the frequency of $\mathrm{T}$ cell populations is much higher in the blood than in the brain, contamination from blood PBMC populations would have resulted in an increase in the frequency of $T$ cells in non-perfused animals as compared to perfused animals. Whole brain tissue was finely minced in 1xHBSS (without Calcium, Magnesium, and phenol red, Invitrogen, 14175) and transferred to an enzymatic DDP solution (DMEM/F12 media containing $1 \mathrm{mg} / \mathrm{mL}$ papain from papaya latex (P4762 Sigma Aldrich, St. Louis, MO), 1.2 U/mL dispase II (4942078001 Roche diagnostics, Risch-Rotkreuz, Switzerland), and 220 U/mL DNAse I (18047-019 Invitrogen, Carlsbad, CA)). The minced tissue and DDP was incubated at $37^{\circ} \mathrm{C}$ for 20 min before being neutralized with 10\% FBS (heat inactivated, Atlanta Biologicals, S11150). The tissue pellet was homogenized in ice-cold 1xHBSS using a fine-tip glass pipette. The homogenate was 
filtered through a $70 \mu \mathrm{M}$ cell strainer. The pellet was resuspended in $37 \%$ Percoll (Percoll pH 8.5-9.5; Sigma Aldrich Co, P1644) and 70\% Percoll layered below, and 30\% Percoll layered above, with 1xHBSS layered on the top. The Percoll gradient was centrifuged and immune cells were collected from the cell cloud between the $70 \%$ and $37 \%$ Percoll layer, washed with $4 \times$ volume of $1 x H B S S$. Cells were split in half and stained with separate antibody panels for flow cytometry; approximately $1 \times 10^{6}$ cells were used per panel.

\subsection{Spleen dissociation for immune cell isolation}

The spleen was removed and placed into 1xHBSS with 5\% FBS. A single cell solution was made by passing tissue through a $70 \mu \mathrm{M}$ cell strainer. Cells were counted on a hemocytometer at a 1 to 10 dilution, and $1 \times 10^{6}$ cells were stained per animal.

\subsection{Deep cervical lymph node dissociation for immune cell isolation}

Both the right and left deep cervical lymph nodes were removed and placed into 1xHBSS with 5\% FBS. A single cell solution was made by passing tissue through a $70 \mu \mathrm{M}$ cell strainer. Cells were counted on a hemocytometer at a 1 to 1 dilution, and $1 \times 10^{6}$ cells were stained per animal.

\subsection{Multi-color flow cytometry}

All cells were stained with Live/Dead Fixable Aqua (1:2000, L34957 Invitrogen) and incubated with anti-mouse CD16/CD32 (1:100, 140161085 eBioscience). $1 \times 10^{6}$ cells from the spleen, deep cervical lymph nodes, and brain were stained with panel 1: anti-mouse CD3 PE eFluor 610 (1:100, 61-0031 eBioscience), anti-mouse CD4 Alexa Fluor 488 (1:100, 53-0041 eBioscience), anti-mouse CD8b APC-eFluor780 (1:100, 47-0083 eBioscience), anti-mouse CD62L PE-Cy7 (1:200, 25-0621 eBioscience), anti-mouse CD44 Alexa Fluor 700 (1:00, 130326 BioLegend) in FACS buffer. One million cells from the brain were stained with panel 2: anti-mouse Ly6G PacBlue (1:100,127611 BioLegend), anti-mouse CD11b FITC (1:100, 11-0112 eBioscience), anti-mouse CD19 PE (1:100, 561736 BD Bioscience), anti-mouse MHCII Pe-Cy7 (1:100, 25-5321 eBioscience), anti-mouse CD45 PerCP-Cy5.5 (1:100, 45-0451 eBioscience), anti-mouse CD3 PE eFluor610 (1:100, 61-0031 eBioscience), anti-mouse CD11c Alexa Fluor 700 (1:50,117320 BioLegend), anti-mouse Ly6C APC-Cy7 (1:100,128026 BioLegend) in FACS buffer. Samples were run on an LSRII (BD Biosciences) and analyzed with FlowJo_V10.

Single cell lymphocytes were gated based on forward scatter height (FSH) (size) and Side Scatter Height (SSH) (granularity) and then by FSH by FHA (forward scatter area). Live cells were then selected as the Fixable Aqua negative population. In the samples stained with panel 1: $\mathrm{CD}^{+}$cells were selected and then gated for $\mathrm{CD} 4^{+}$and $\mathrm{CD} 8^{+}$. Each of the $\mathrm{CD} 4^{+}$ and $\mathrm{CD} 8^{+}$gated populations were gated by $\mathrm{CD} 44$ vs $\mathrm{CD} 62 \mathrm{~L}$. In samples stained with panel 2: $\mathrm{CD} 45^{+}$cells were selected and then gated by CD3 ( $\mathrm{T}$ cells) vs Ly6G (Neutrophils). The $\mathrm{CD}^{-}{ }^{-} \mathrm{Ly}_{6 \mathrm{G}^{-}}$population was gated $\mathrm{CD} 19$ vs $\mathrm{CD} 11 \mathrm{~b}$ and the $\mathrm{CD} 11 \mathrm{~b}^{+} \mathrm{CD} 19^{-}$population was gated for $\mathrm{CD} 45^{\text {high }}$ and $\mathrm{CD} 45^{\text {low }}$ populations. Those populations were gated for $\mathrm{MHCII}^{+}$ and $\mathrm{MHCII}^{-}$and $\mathrm{Ly}_{6} \mathrm{C}^{\text {high }}$ and $\mathrm{Ly} 6 \mathrm{c}^{\text {low }}$ from histogram distribution. The $\mathrm{CD} 11 \mathrm{~b}^{+} \mathrm{CD} 19^{-}$ population was also gated for $\mathrm{CD} 11 \mathrm{c}$, a marker of dendritic cells and potentially of a subpopulation of antigen presenting microglia (Wlodarczyk et al., 2014). From every sample 
counting beads (AccuCheck Counting Beads, Invitrogen PCB100, $10 \mu \mathrm{L}$ were added to each sample before running on the LSRII) were selected on size from the FSH vs FHA plot and then again from FSH vs FHA. Sample counts of all target populations were calculated in FlowJo and from these counts total tissue counts were obtained: ((population count/bead count $) \times$ bead concentration in sample run $) \times$ run volume $\times($ whole sample volume/volume processed for $1 \times 10^{6}$ cells).

For assessment of immune cells populations at 3.5, 5, 7, and 12 months the following group sizes of female 5xFAD were used: 3.5 months: non- $\operatorname{Tg} n=8, \operatorname{Tg} n=9 ; 5$ months: non- $\operatorname{~} \mathrm{n}$ $=11, \operatorname{Tg} \mathrm{n}=11 ; 7$ months: non- $\operatorname{Tg} \mathrm{n}=11, \operatorname{Tg} \mathrm{n}=13 ; 12$ months: $\operatorname{non}-\operatorname{Tg} \mathrm{n}=10, \operatorname{Tg} \mathrm{n}=9$. Within these groups, subsets with robust MHCII and Ly6C staining were used for analysis of these markers in the brain, non-robust staining was determined as antibody or experimental error and not specific to treatment group or genotype: 3.5 months: non-Tg $\mathrm{n}=8$ (MHCII) $/ 5$ (Ly6C), $\operatorname{Tg} n=9 / 4 ; 5$ months: non- $\operatorname{Tg} n=4 / 7, \operatorname{Tg} n=7 / 8 ; 7$ months: non- $\operatorname{Tg} n=8 / 6, \operatorname{Tg} n=$ 11/7; 12 months: non- $\operatorname{Tg} n=9 / 10, \operatorname{Tg} n=8 / 4$. From the overall group, a subset of samples had robust CD44 and CD62L staining and were used for analyses of those markers in brain 3.5 months non- $\operatorname{Tg} n=5, \operatorname{Tg} n=3 ; 5$ months: non- $\operatorname{Tg} n=4, \operatorname{Tg} n=4 ; 7$ months: non- $\operatorname{Tg} n=$ $5, \operatorname{Tg} n=5 ; 12$ months: non- $\operatorname{Tg} n=6, \operatorname{Tg} n=4$.

\subsection{XPro1595 administration}

XPro1595 is a PEG-ylated human TNF variant devoid of TNF receptor-binding activity that forms heterotrimers with native sTNF (but not membrane-bound TNF), thereby sequestering sTNF away from TNF receptors (Steed et al., 2003; Barnum et al., 2014). To assess the role of sTNF in AD-like pathology and immune cell trafficking to the CNS, Tg female mice were divide into two cohorts each with two treatment groups. Mice received either subcutaneous (s.c.) saline vehicle control or s.c. XPro1595 $(10 \mathrm{mg} / \mathrm{kg})$ twice weekly for two months. This dose was selected on the basis of PK/PD studies and its efficacy in reducing dopaminergic neuron loss and glial activation in a rat model of nigral degeneration (Barnum et al., 2014). When administered peripherally, XPro1595 is detectable in the brain (1 and $6 \mathrm{ng} / \mathrm{mL}$ of is detectable in the brain (Supp Fig. S1) which is sufficient to neutralize the native soluble homotrimer TNF through soluble heterotrimer formation; To assess the role of sTNF on trafficking immune cell population one cohort of female mice was treated between 5 and 7 months of age (Saline $n=9$, XPro1595 $n=10$ ); within this group, $n=9$ saline and $n=7$ XPro1595 were used for analysis of the Ly6C marker within the myeloid panel, and $\mathrm{n}=5$ saline and $\mathrm{n}=6$ XPro1595 were used for analysis of CNS T cell panel in addition to the CNS myeloid panel). The other cohort was treated with XPro1595 or saline between 2 and 4 months of age (Saline $n=8$ and XPro1595 $n=7$ ). XPro1595 (generously provided by Dr. David Szymkowski at Xencor, Inc.) was diluted with sterile saline to $2 \mathrm{mg} / \mathrm{mL}$ concentration to be dosed in mice at $10 \mathrm{mg} / \mathrm{kg}$. To assess the role of sTNF on AD-like amyloid accumulation and mRNA associated with inflammatory markers female $\mathrm{Tg}$ and non-Tg mice treated with either saline or XPro1595 from 5 to 7 months of age (non- $T g$ saline $n=8$, non$\operatorname{Tg}$ XPro1595 $n=6, \operatorname{Tg}$ saline $n=3, \operatorname{Tg}$ XPro1595 $n=5$ ). 


\subsection{Electrophysiology}

Brain slice electrophysiology methods were performed as previously published (Mathis et al., 2011; Bachstetter et al., 2012; Furman et al., 2012). The study design was the same as for the mice used for immunological and histological outcome measures. After eight weeks of i.p. injections, mice were deeply anesthetized with $\mathrm{CO}_{2}$ and decapitated. Brains were removed and stored briefly in ice-cold, $\mathrm{Ca}^{2+}$-free artificial cerebrospinal fluid (ACSF) containing (in mM) $124 \mathrm{NaCl}, 2 \mathrm{KCl}, 1.25 \mathrm{KH}_{2} \mathrm{PO}_{4}, 2 \mathrm{MgSO}_{4}, 26 \mathrm{NaHCO}_{3}, 10$ dextrose $(\mathrm{pH}=7.4)$, and saturated with $95 \% \mathrm{O}_{2}$ and $5 \% \mathrm{CO}_{2} .400 \mu \mathrm{m}$-thick sections were cut on a Vibratome ${ }^{\circledR} 1000$ vibrating microtome (Leica Biosystems, Buffalo Grove, IL). Slices were then transferred to a custom holding chamber (Mathis et al., 2011) and maintained in $\mathrm{CaCl}_{2}-$ containing $(2 \mathrm{mM})$-ACSF at an interface with warm $\left(32^{\circ} \mathrm{C}\right)$, humidified air. Slices were permitted to equilibrate for at least $1.5 \mathrm{~h}$ before beginning electrophysiological analysis. Investigators were blinded to treatment history.

Slices were transferred to an RC-27 recording chamber (Warner Instruments, Hamden, CT) and perfused with oxygenated $\operatorname{ACSF}\left(32{ }^{\circ} \mathrm{C}\right)$ at a rate of $1-2 \mathrm{~mL} / \mathrm{min}$ for $15-20 \mathrm{~min}$ before the start of each recording session. CA3 Schaffer collaterals were activated with a bipolar platinum-iridium electrode located in stratum radiatum near the CA3 border. Stimulus intensity was controlled by a constant current stimulus isolation unit (World Precision Instruments, Sarasota, FL), and stimulus timing was controlled by Clampex 9.2 software (Molecular Devices, Sunnyvale, CA). Field EPSPs were recorded using a glass micropipette (1-6 M $\Omega$ ), filled with ACSF and containing an $\mathrm{Ag}-\mathrm{AgCl}$ wire, positioned in stratum radiatum of CA1, approximately 1-2 $\mathrm{mm}$ away from the point of stimulation. Field potentials were amplified $100 \times$, Bessel-filtered at $1 \mathrm{kHz}$, and digitized at $10 \mathrm{kHz}$ using a Multiclamp 700B amplifier and a Digidata 1320 digitizer (Molecular Devices).

To assess basal synaptic strength, twin stimulus pulses ( $\mathrm{S} 1$ and $\mathrm{S} 2,100 \mu$ s pulse duration, 50 ms interpulse interval) were given at 12 intensity levels (range $25-500 \mu \mathrm{A}$ ) at a rate of 0.1 Hz. Five field potentials at each level were averaged, and measurements of fiber volley (FV) amplitude (in $\mathrm{mV}$ ) and excitatory postsynaptic potential (EPSP) slope ( $\mathrm{mV} / \mathrm{ms}$ ) for $\mathrm{S} 1$ were performed offline using ClampFit software (Molecular Devices). Synaptic strength curves were constructed by plotting the EPSP slope against the FV amplitude at each stimulus intensity. Maximal synaptic strength for each slice was estimated by taking the maximal EPSP slope amplitude during the input/output curve and dividing by the corresponding FV amplitude. Paired-pulse facilitation (PPF) was calculated by dividing the S2 EPSP slope by the S1 EPSP (taken from the linear portion of the synaptic strength curve) and multiplying by 100. To estimate population spike (PS) threshold, the EPSP slope amplitude at which a population spike first appeared in the ascending phase of the field potential was calculated and averaged across five successive trials at the spike threshold stimulation level.

After synaptic strength curves were constructed, the stimulus intensity was readjusted to elicit an EPSP of $\sim 1 \mathrm{mV}$, and stimulus pulses were delivered at $0.033 \mathrm{~Hz}$ until a stable 20 min baseline was established. High-frequency stimulation (two $100 \mathrm{~Hz}$ trains, $1 \mathrm{~s}$ each, $10 \mathrm{~s}$ intertrain interval) was then delivered at the baseline stimulation intensity to induce LTP, followed by an additional $60 \mathrm{~min}$ baseline. Within each group, EPSP slope measures from the last 10 min of the post-LTP baseline were averaged across slices within each animal and 
compared to the pre-LTP baseline slope average. Electrophysiological parameters were averaged across all slices within each animal (one to three slices), and the $n$ used for statistical comparisons reflects the number of animals per genotype and treatment group.

\subsection{Brain dissection for RNA extraction}

Mice were rapidly decapitated under isoflurane and the brain was removed. Half of the brain was post fixed for immunohistochemistry (see below). From the other half, the cerebellum, midbrain, hippocampus, and cortex were dissected out on a cold glass petri dish. Tissue was fast cooled in liquid nitrogen and stored at $-80 \mathrm{C}^{\circ}$ until processing. Tissue was processed by first homogenizing in Trizol (Life Technologies, 1596018) with a Tissue LyserII (Retsch). mRNA was isolated with RNeasy kit (Qiagen, 74106) and treated with DNAase1 (Invitrogen, 18068).

\subsection{Real-time PCR (qPCR)}

To assess baseline inflammation at 2,4 and 6 months of age, tissue was collected from the same mice used for the CSF collection (2 months: Tg 4 Male and 4 Female, non-Tg 5 Male and 9 Female; 4 months: Tg 4 Male and 6 Female, non-Tg 6 Male and 4 Female; 6 months: Tg 3 Male and 4 Female, non-Tg 7 Male and 7 Female) and assessed for expression of mRNA associated with pro-inflammatory cytokines. To assess hippo-campal inflammation and the role of sTNF tissue was collected from female $\mathrm{Tg}$ and non- $\mathrm{Tg}$ mice treated with either saline or XPro1595 from 5 to 7 months of age (non-Tg saline $n=8$, non-Tg XPro1595 $n=6, \operatorname{Tg}$ saline $n=3, \operatorname{Tg}$ XPro1595 $n=5$ ), only half of the brain was use the other half was post fixed for immunohistochemistry, below. Power analysis (75\%) to determine significant effect of TNF mRNA in hippocampus due to genotype $(\mathrm{Tg}$ mean $=5.390$, non- $\mathrm{Tg}$ mean $=$ $1.103, \mathrm{SD}=1.992$ ) determined a samples size $=3$ is sufficient.

Reverse transcription was preformed to make cDNA as published previously (Kannarkat et al., 2015). Briefly, cDNA was used with the following primer sets for qPCR, with TATA binding protein used as a housekeeping control to normalize samples: TNF - Forward 5' CTG AGG TCA ATC TGC CCA AGT AC 3' Reverse 5' CTT CAC AGA GCA ATG ACT CCA AAG 3'; CCL2 - Forward 5' CTT CCT CCA CCA CCA TGC A 3' Reverse 5' CCA GCC GGC AAC TGT GA 3'; TGF $\beta$ - Forward 5' GCA GTG GCT GAA CCA AGG A 3' Reverse $5^{\prime}$ AGA GCA GTG AGC GCT GAA TC $3^{\prime} ;$;L- $1 \beta$ - Forward $5^{\prime}$ CAA CCA ACA AGT GAT ATT CTC CAT G 3' Reverse 5' GAT CCA CAC TCT CCA GCT GCA 3'; TATA binding protein - Forward 5' GTA TCT GCT GGC GGT TTG G 3' Reverse 5' GGC ACT GCG GAG AAA ATG A 3'; CD45 - Forward 5' TCA TGG TCA CAC GAT GTG AAG A 3' Reverse 5' AGC CCG AGT GCC TTCCT3';TNFR1 - Forward 5' GTC CAT TCT AAG AAC AAT TCC ATC TG $3^{\prime}$ Reverse $5^{\prime}$ GCT CGG ACA GTC ACT CAC CAA $3^{\prime}$;TNFR2 - Forward 5' CTA TGA CAG GAA GGC TCA GAT GTG 3' Reverse 5'GTG TCC GAG GTC TTG TTG CA $3^{\prime} ;$ IFN $\gamma$ R - Forward 5' GAC GTC TGT ATC CCT CCT TTC C $3^{\prime}$ Reverse 5' GTA AGA GGA GCA ACC ACC AGA A 3'.

\subsection{Brain dissociation for immunohistochemistry and histological analysis}

Female Tg and Non-Tg mice treated with XPro1595 or saline from 5 to 7 months of age (non- $\operatorname{Tg}$ saline $n=8$, non-Tg XPro1595 $n=6, \operatorname{Tg}$ saline $n=3, \operatorname{Tg}$ XPro1595 $n=5$ ) were 
rapidly decapitated under isoflurane and the brain was removed. Half of the brain was post fixed for immunohistochemistry in 4\% PFA for $24 \mathrm{~h}$ and then transferred to $30 \%$ sucrose in 1xPBS. Brains ( $n=4$ per treatment group) were embedded and sectioned at $35 \mu \mathrm{M}$; serial sections were stained with anti-Amyloid- $\beta$ (6e10), counterstained with thionine, and Amino Cupric Silver staining for to measure disintegration of multiple neuronal elements including cell bodies, axons, dendrites, and synaptic terminals, and counterstained with Nissl red by NeuroScience Associates (Knoxville, TN). Slides were scanned using the Aperio System (Leica Biosystems). Regions of interest were outlined and analyzed in ImageScope (Leica Biosystems). Sections stained with $6 \mathrm{e} 10$ were analyzed with the algorithm (positive pixel count), positive and strong positive pixels were used to measure amyloid density. Sections stained with amino cupric silver were analyzed with a modified algorithm with the following settings: Hue value 0.1, Hue width 0.8, CST 0.04, Iwp (high) 200, Iwp (low) 175, Ip (low) 110 , Isp (low) 0 , Inp (high) -0.8 . Only strong positive pixels were used to measure early cellular degradation.

\subsection{Statistical analysis}

Synaptic strength parameters and LTP values were compared across genotypes and drug treatment conditions with two-way analysis of variance (ANOVA) using GraphPad Prism 6 software (La Jolla, CA). Fisher's PLSD was used for post hoc comparisons. Cytokine protein values from multiplexed immunoassay analyses were compared across genotypes with in each age using non-parametric $t$-test using GraphPad Prism 6 software. qPCR data for aging evaluation of inflammatory mRNA data was normalized to 2 mo non-Tg and were compared across genotypes and age with two-way ANOVA. Sidak's multiple comparisons test was used for post hoc comparisons within each age. Data from immunophenotyping studies across age was compared across genotypes and age with two-way ANOVA. Sidak's multiple comparisons test was used for post hoc comparisons within each age. Effects of XPro1595 on Tg immune cell populations, 6E10, and immune cupric Ag reactivity were determined across treatment using non-parametric $t$-test using GraphPad Prism 6 software. XPro1595 effects on mRNA expression were normalized to non-tg saline and analyzed across genotypes and drug treatment conditions with two-way ANOVA. Sidak's multiple comparisons test was used for post hoc comparisons within genotype. Significance for all statistical comparisons was set at $\mathrm{p} \leq 0.05$. All data are presented as mean \pm SEM.

\section{Results}

\subsection{Age-dependent pro-inflammatory cytokine expression in 5xFAD mice}

The 5xFAD (Tg) mouse model of Alzheimer's disease displays progressive amyloid beta plaque accumulation before 3 months of age, progressive synaptic protein loss as well as later neuronal degeneration, and cognitive deficits by 5 months of age (Oakley et al., 2006). In this model we found age-dependent and region-specific increases in inflammatory mRNAs within the CNS but minimal evidence of inflammation in the CSF, as measured by multiplexed immunoassay. Tg mice, male and female, were not found to express significantly different levels of several cytokines in CSF at 2, 4, or 6 months of age. Levels of $\mathrm{mKC} / \mathrm{CXCL} 1$ protein are significantly lower in Tg mice at 6 months of age (non-Tg mean $7.962 \pm 0.438 \mathrm{pg} / \mathrm{mL} ; \mathrm{Tg}$ mean $4.3033 \pm 1.481 \mathrm{pg} / \mathrm{mL}$ df $=5 \mathrm{t}=2.724 \mathrm{p}<0.05 *$, Table $1 \mathrm{~A}$; 
CSF levels of INF $\gamma$, IL-10, IL-1 $\beta$, IL-6 and IL-12 p70 protein levels undetectable). TNF protein levels are not detectable at 2 month of age and no significant differences were found at 4 and 6 months of age. Within the cortex, there was a significant increase in expression of CD45 mRNA at 6 months Tg mice as compared to non-Tg mice, male and female, (non-Tg mean $=1.188 \pm 0.138$ fold change, $\mathrm{Tg}$ mean $=2.901 \pm 0.415$ fold change from 2 month nonTg baseline by 2 -way ANOVA $\mathrm{df}=58 \mathrm{t}=7.107 \mathrm{p}<0.0001$, Table 1B). Within the midbrain, expression of CD45 and TNF mRNA was significantly increased at 6 months in Tg mice as compared to non-Tg mice (TNF: non- $\mathrm{Tg}=1.21 \pm 0.147, \mathrm{Tg}=3.325 \pm 0.731$ fold change from 2 month non- $\mathrm{Tg}$ baseline by 2-way ANOVA $\mathrm{df}=57, \mathrm{t}=5.560, \mathrm{p}<0.05$; CD45: non$\mathrm{Tg}=1.122 \pm 0.074, \mathrm{Tg}=3.276 \pm 0.586$ fold change from 2 month non- $\mathrm{Tg}$ baseline by $2-$ way ANOVA df $=58 \mathrm{t}=7.895 \mathrm{p}<0.0001$, Table 1B).

\subsection{Altered peripheral immune cell populations in the pro-inflammatory $\mathrm{Tg}$ CNS environment}

Immune cells were isolated from the CNS of $\mathrm{Tg}$ and non-Tg mice at 3.5, 5, 7, and 12 months of age. These ages correspond to early stages of amyloid deposition (3.5 months), onset of cognitive impairment (5 months), and aggressive amyloid burden (7 and 12 months) (Oakley et al., 2006). Here, we show that populations of immune cells trafficking into the brain were altered between $\mathrm{Tg}$ and non-Tg mice as a function of age. Peripheral macrophages that have trafficked into the brain are $\mathrm{CD} 11 \mathrm{~b}^{+}$and $\mathrm{CD} 45^{\text {high }}$. $\mathrm{CD} 45^{\text {high }} \mathrm{CD} 11 \mathrm{~b}^{+}$cells historically have been identified solely as peripheral macrophages however microglia, while they are in majority CD45 low , have been shown to be capable of expression CD45 at high levels when activated (Sedgwick et al., 1991). Thus our $\mathrm{CD} 45^{\text {high }} \mathrm{CD} 11 \mathrm{~b}^{+}$population was not purely peripheral macrophages but also contained activated microglia and dendritic cells, which also express CD11b and CD45 at high level; neutrophils were gated out of this population using the marker Ly6G (Rose et al., 2012). Within the brain, there was no effect of genotype or age on the number of $\mathrm{CD} 11 \mathrm{~b}^{+} \mathrm{CD} 45^{\text {high }}$ cells (data not shown), however within this population there was a significant decrease in the

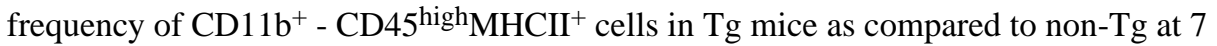
months of age, $($ non- $\mathrm{Tg}=4.240 \pm 0.213 \%, \mathrm{Tg}=2.601 \pm 0.316 \%$ by 2 -way ANOVA $\mathrm{df}=53$ $\mathrm{t}=5.061 \mathrm{p}<0.0001$, Fig. 1B). MHCII is used by antigen presenting cells, such as macrophage and microglia of the innate immune system, activate $\mathrm{CD} 4^{+} \mathrm{T}$ cells of the adaptive immune system (Neefjes et al., 2011). In Tg mice, there was a significant increase in the ratio of $\mathrm{CD} 11 \mathrm{~b}^{+}$Ly6 $\mathrm{C}^{\text {high }}$ :Ly6 $6 \mathrm{C}^{\text {low }}$ at 5 months in the brain as compared to non- $\mathrm{Tg}$ mice, $($ non- $\mathrm{Tg}=0.098 \pm 0.004, \mathrm{Tg}=0.171 \pm 0.018$ by 2 -way ANOVA df $=38 \mathrm{t}=2.722 \mathrm{p}<$ 0.05 , Fig. 1B).

Immune cells, including $\mathrm{T}$ cells, neutrophils, and dendritic cells, will traffic to tissues including the brain to conduct immune surveillance and respond to inflammation (Ransohoff and Brown, 2012; Ransohoff and Engelhardt, 2012). In the brain of Tg and non-Tg mice, there were no significant differences in the frequency or number of neutrophils (CD3-

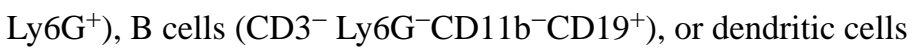

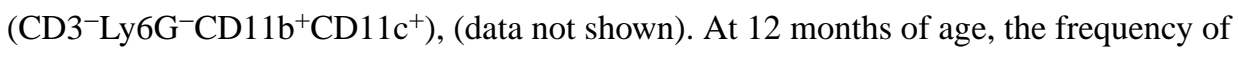
$\mathrm{CD}^{+} \mathrm{T}$ cells of all $\mathrm{CD} 45^{+}$brain cells was significantly increased in $\mathrm{Tg}$ mice as compared to non- $\mathrm{Tg}$ mice $($ non- $\mathrm{Tg}=20.822 \pm 2.919 \% \mathrm{Tg}=34.000 \pm 3.506 \%$ by 2 - way ANOVA df $=72$ 
$\mathrm{t}=3.636 \mathrm{p}<0.01$, Fig. 1C). Within this population, $\mathrm{CD} 4^{+}$and $\mathrm{CD} 8^{+} \mathrm{T}$ cells were measured (Fig. 1C). The number of $\mathrm{CD}^{+} \mathrm{T}$ cells was not significantly different between $\mathrm{Tg}$ and non$\mathrm{Tg}$ mice, however, at 12 months of age, there was a significant increase in the number of $\mathrm{CD}^{+} \mathrm{T}$ cells in the brains of $\mathrm{Tg}$ mice as compared to non- $\mathrm{Tg}$ mice (non- $\mathrm{Tg}=5622.937$ $\pm 1238.101 \mathrm{Tg}=13.098 .990 \pm 2637.522$ by 2 - way ANOVA $\mathrm{df}=67 \mathrm{t}=3.903 \mathrm{p}<0.001$, Fig. 1D). Within the $\mathrm{CD} 8^{+} \mathrm{T}$ cell population, naïve, effector, and memory subtypes were assessed via expression of CD62L and CD44 expression level. Tg mice show alterations of the $\mathrm{CD}^{+}$effector $\left(\mathrm{CD}^{2} \mathrm{~L}^{-} \mathrm{CD}^{-} 4^{-}\right) \mathrm{T}$ cell population as compared to non-Tg. At 3.5 months of age, there was a significant decrease in the frequency of $\mathrm{CD} 8^{+}$effectors (non- $\mathrm{Tg}$ $=73.125 \pm 3.744 \% \mathrm{Tg}=42.978 \pm 14.773 \%$ by 2 -way ANOVA $\mathrm{df}=37 \mathrm{t}=2.692 \mathrm{p}<0.05$, Fig. 1E), and at 5 months of age, there was a significant increase in the number of CD8 ${ }^{+}$ effectors (non- $\mathrm{Tg}=3166.673 \pm 661.671 \mathrm{Tg}=5604.624 \pm 902.898$ by 2 -way ANOVA $\mathrm{df}=$ $36 \mathrm{t}=2.979 \mathrm{p}<0.05$, Fig. 1E). No significant changes were detected in the other subpopulations of $\mathrm{CD}^{+}$or $\mathrm{CD} 4^{+} \mathrm{T}$ cells (data not shown).

\subsection{Altered naïve and effector $\mathrm{T}$ cell populations in deep cervical lymph nodes of $\mathrm{Tg}$ mice}

No significant differences in the number of $\mathrm{CD}^{+}$or $\mathrm{CD} 8^{+} \mathrm{T}$ cells were found in the DCLNs or spleen between $\mathrm{Tg}$ and non-Tg mice (data not shown). However, within the $\mathrm{CD} 4^{+}$and $\mathrm{CD} 8^{+} \mathrm{T}$ cell populations in the DCLN, but not spleen (data not shown), $\mathrm{Tg}$ mice showed increased frequency of $\mathrm{CD} 4^{+}$and $\mathrm{CD} 8^{+}$naïve $\left(\mathrm{CD} 62 \mathrm{~L}^{+} \mathrm{CD} 44^{\text {low }}\right) \mathrm{T}$ cells, and decreased frequency of effector $\mathrm{T}$ cells, at 5 months $\left(\mathrm{CD}^{+}\right.$naïve non- $\mathrm{Tg}=55.825 \pm 5.198 \% \mathrm{Tg}=$ $75.425 \pm 3.123 \%$ by 2 -way ANOVA $\mathrm{df}=29 \mathrm{t}=2.927 \mathrm{p}<0.05, \mathrm{CD}^{+}$effector non- $\mathrm{Tg}=$ $36.375 \pm 5.344 \% \mathrm{Tg}=15.450 \pm 1.023 \%$ by 2 -way ANOVA $\mathrm{df}=28 \mathrm{t}=3.796 \mathrm{p}<0.01$, Fig. $2 \mathrm{~A} ; \mathrm{CD}^{+}$naïve non- $\mathrm{Tg}=51.000 \pm 3.143 \% \mathrm{Tg}=70.025 \pm 2.885 \%$ by 2 -way ANOVA $\mathrm{df}=$ $29 \mathrm{t}=3.123 \mathrm{p}<0.05, \mathrm{CD}^{+}$effector non- $\mathrm{Tg}=38.650 \pm 3.847 \% \mathrm{Tg}=22.075 \pm 2.893 \%$ by 2-way ANOVA df $=28 \mathrm{t}=2.841 \mathrm{p}<0.05$, Fig. 2B). In the DCLN, CD4 ${ }^{+}$and CD8 ${ }^{+} \mathrm{T}$ cell subsets shifted with age towards memory phenotypes. Frequency of both central and effector memory $\mathrm{CD}^{+}{ }^{+} \mathrm{T}$ cells subsets was significantly increased at 12 months in both genotypes from all other time points in both spleen and DCLNs (data not shown). Frequency of central memory CD ${ }^{+} \mathrm{T}$ cells was significantly increased at 12 months in both genotypes from all other time points in both spleen and DCLNs (data not shown). Frequency of effector memory $\mathrm{CD}^{+} \mathrm{T}$ cells was significantly decreased in the DCLNs in Tg mice as compared to non- $\mathrm{Tg}$ mice at 12 months of age, (non- $\mathrm{Tg}=7.598 \pm 0.518 \% \mathrm{Tg}=4.473 \pm 1.197 \%$ by 2 way ANOVA df $=29 \mathrm{t}=3.111 \mathrm{p}<0.05$ (data not shown)).

\subsection{Inhibition of soluble TNF decreases brain populations of activated CD11b+ immune cells and $\mathrm{CD4}^{+} \mathrm{T}$ cells}

$\mathrm{Tg}$ mice were treated with s.c. XPro1595 $(10 \mathrm{mg} / \mathrm{kg})$ twice weekly for two months starting at 5 months of age or starting at 2 months of age to assess the role of sTNF on AD-like pathology after significant plaque deposition or as plaque deposition begins to build up, respectively. Inhibition of soluble TNF with XPro1595 between 5 and 7 months of age decreased $\mathrm{MHCII}^{+}$microglia/macrophages within both populations of activated microglia/ peripheral cells (CD11 ${ }^{+} \mathrm{CD} 45^{\text {high }}$;frequency but not number) and quiescent/homeostatic resident microglia $\left(\mathrm{CD} 11 \mathrm{~b}^{+} \mathrm{CD} 45^{\text {low; }}\right.$ frequency and number) immune cells (activated/ peripheral $\mathrm{MHCII}^{+}$: frequency - non- $\mathrm{Tg}=5.811 \pm 0.5256 \% \mathrm{Tg}=3.843 \pm 0.2614 \%$ by 
unpaired $t$-test $\mathrm{df}=16 \mathrm{t}=3.352 \mathrm{p}<0.01$, number - non- $\mathrm{Tg}=1676 \pm 186.7 \mathrm{Tg}=1334$ \pm 174.7 by unpaired $t$-test $\mathrm{df}=16 \mathrm{t}=1.331 \mathrm{p}=0.2020$; quiescent/homeostatic $\mathrm{MHCII}^{+}$:frequency - non- $\mathrm{Tg}=4.440 \pm 0.4430 \% \mathrm{Tg}=2.678 \pm 0.3250 \%$ by unpaired $t$-test $\mathrm{df}$ $=17 \mathrm{t}=3.252 \mathrm{p}<0.01$, number - non- $\mathrm{Tg}=1309 \pm 233.0 \mathrm{Tg}=744.2 \pm 113.6$ by unpaired $t-$ test $\mathrm{df}=15 \mathrm{t}=2.260 \mathrm{p}<0.05$, Fig. 3A). While these effects on $\mathrm{MHCII}^{+}$populations were not observed in Tg mice dosed between 2 and 4 months of age, there was an overall decrease in the frequency of $\mathrm{CD} 11 \mathrm{~b}^{+} \mathrm{CD} 45^{\text {high }}$ populations and an increase in $\mathrm{CD} 11 \mathrm{~b}^{+} \mathrm{CD} 45^{\text {low }}$ populations $\left(\mathrm{CD} 45^{\text {high }}-\right.$ non- $\mathrm{Tg}=15.44 \pm 1.633 \% \mathrm{Tg}=10.53 \pm 1.14 \% 2$ by unpaired $t$-test $\mathrm{df}=12 \mathrm{t}=2.293 \mathrm{p}<0.05 ; \mathrm{CD} 45^{\text {low }}-$ non $-\mathrm{Tg}=84.51 \pm 1.639 \% \mathrm{Tg}=89.43 \pm 1.147 \%$ by unpaired $t$-test $\mathrm{df}=12 \mathrm{t}=2.290 \mathrm{p}<0.05$, Fig. 3F).

Xpro1595 from 5 to 7 months in Tg mice decreased the ratio of Ly6C $\mathrm{C}^{\text {high }}: \mathrm{Ly} 6 \mathrm{C}^{\text {low }} \mathrm{CD} 11 \mathrm{~b}^{+}$ immune cells however the individual cell counts of Ly6 $\mathrm{C}^{\text {high }}$ and $\mathrm{Ly} 6 \mathrm{C}^{\text {low }}$ populations were not significantly different with XPro1595 treatment $\left(\right.$ Ly6 $\mathrm{C}^{\text {high }}$ :Ly6C ${ }^{\text {low }}$ - non- $\mathrm{Tg}=0.2133$ $\pm 0.02147 \mathrm{Tg}=0.1335 \pm 0.02178$ by unpaired $t$-test $\mathrm{df}=14 \mathrm{t}=2.571 \mathrm{p}<0.05 ;$ Ly6C $\mathrm{C}^{\text {high }}$ count - non- $\mathrm{Tg}=822.1 \pm 163.3 \mathrm{Tg}=630.5 \pm 125.5$ by unpaired $t$-test $\mathrm{df}=14 \mathrm{t}=0.8855, \mathrm{p}=$ n.s., Ly6C $\mathrm{C}^{\text {low }}$ count - non-Tg $=4084 \pm 741.1 \mathrm{Tg}=5921 \pm 1625$ by unpaired $t$-test $\mathrm{df}=14 \mathrm{t}=$ $1.112 \mathrm{p}=$ n.s., Fig. 3B). When mice were dosed between 2 and 4 months of age, there was a trend for a decreased ratio of Ly6 $\mathrm{C}^{\text {high }}: \mathrm{Ly} 6 \mathrm{C}^{\text {low }}$ of $\mathrm{CD} 11 \mathrm{~b}^{+}$immune cells in Tg mice $\left(\right.$ Ly6C $C^{\text {high }}:$ Ly6C $C^{\text {low }}-$ non-Tg $=0.1225 \pm 0.01449 \mathrm{Tg}=0.08311 \pm 0.01334$ by unpaired $t$-test $\mathrm{df}=12 \mathrm{t}=1.933 \mathrm{p}=0.0772$, Fig. $3 \mathrm{G})$.

Among the other immune cell populations in the brain, no changes were detected in frequency or number of B cells or neutrophils when XPro1595 was dosed from 5 to 7 months of age in $\mathrm{Tg}$ mice (data not shown). Within the dendritic cell population, there was a significant increase in frequency of $\mathrm{CD} 11 \mathrm{c}^{+}$cell population in the brain $\left(\mathrm{CD} 11 \mathrm{~b}^{+}-\mathrm{CD} 11 \mathrm{c}^{+}\right.$ Frequency - non- $\mathrm{Tg}=10.12 \pm 0.8053 \% \mathrm{Tg}=16.78 \pm 12.116 \%$ by unpaired $t$-test $\mathrm{df}=14 \mathrm{t}=$ $3.229 \mathrm{p}<0.001$ ); however there was no significant increase in cell number (data not shown). When mice were dosed with XPro1595 between 2 and 4 months of age, there was no significant increase in the number or frequency of $\mathrm{CD} 11 \mathrm{c}^{+}$cells within the $\mathrm{CD} 11 \mathrm{~b}^{+}$ population (data not shown). Within this population, only when XPro1595 was dosed between 2 and 4 month of age but not when dosed between 5 and 7 months of age, there was a significant decrease in the frequency of a $\mathrm{MHCII}^{+}$populations $\left(\mathrm{CD} 11 \mathrm{~b}^{+} \mathrm{CD} 11 \mathrm{c}^{+} \mathrm{MHCII}^{+} 2-4\right.$ months XPro1595: non $-\mathrm{Tg}=5.775 \pm 0.7116 \% \mathrm{Tg}=3.113$ $\pm 0.2031 \%$ by unpaired $t$-test $\mathrm{df}=12 \mathrm{t}=3.138 \mathrm{p}<0.01$ ).

In Tg mice treated with XPro1595 from 5 to 7 months, $\mathrm{CD}^{+} \mathrm{T}$ cell populations were decreased by XPro1595 treatment in frequency but not in number $\left(\mathrm{CD} 3^{+}\right.$Frequency - non$\mathrm{Tg}=24.64 \pm 1.817 \% \mathrm{Tg}=18.88 \pm 1.349 \%$ by unpaired $t$-test $\mathrm{df}=16 \mathrm{t}=2.548 \mathrm{p}<0.05$, Count - non- $\mathrm{Tg}=14.427 \pm 1390 \mathrm{Tg}=11.963 \pm 1829$ by unpaired $t$-test $\mathrm{df}=17 \mathrm{t}=1.054 \mathrm{p}=$ n.s., Fig. $3 \mathrm{C}$ ). Within the T cell population, inhibition of sTNF did not induce any significant changes within the $\mathrm{CD} 8^{+} \mathrm{T}$ cell population $\left(\mathrm{CD}^{+} \mathrm{T}\right.$ cell count non- $\mathrm{Tg}=9333 \pm 2233 \mathrm{Tg}=$ $6811 \pm 1572$ by unpaired $t$-test $\mathrm{df}=11 \mathrm{t}=0.9509 \mathrm{p}=$ n.s.; CD8 ${ }^{+}$Effector $\mathrm{T}$ cell count non$\mathrm{Tg}=7536 \pm 1876 \mathrm{Tg}=4234 \pm 786.1$ by unpaired $t$-test $\mathrm{df}=8 \mathrm{t}=1.623 \mathrm{p}=\mathrm{n}$.s. Fig. 3E); however, there was a significant decrease in the number of $\mathrm{CD}^{+} \mathrm{T}$ cells and a trend for decreased number of $\mathrm{CD} 4^{+}$effector T cells in Tg mice treated with XPro1595 between 5 and 
7 months of age $\left(\mathrm{CD} 4^{+} \mathrm{T}\right.$ cell count - non- $\mathrm{Tg}=4244 \pm 725.7 \mathrm{Tg}=2369 \pm 305.9$ by unpaired $t$-test $\mathrm{df}=11 \mathrm{t}=2.746 \mathrm{p}<0.05, \mathrm{CD} 4^{+}$effector $\mathrm{T}$ cell count - non- $\mathrm{Tg}=4151$ $\pm 734.9 \mathrm{Tg}=2263 \pm 427.5$ by unpaired $t$-test $\mathrm{df}=8 \mathrm{t}=2.221 \mathrm{p}=0.0571$, Fig. 3D). Inhibition of sTNF from 2 to 4 months did not produce any significant effects in $\mathrm{T}$ cells populations in $\mathrm{Tg}$ mice $\left(\mathrm{CD} 8^{+} \mathrm{T}\right.$ cell count - non- $\mathrm{Tg}=3010 \pm 508.8 \mathrm{Tg}=7872 \pm 3025$ by unpaired $t$-test $\mathrm{df}=12 \mathrm{t}=1.834 \mathrm{p}=$ n.s., $\mathrm{CD}^{+} \mathrm{T}$ cell count - non- $\mathrm{Tg}=1886 \pm 308.9 \mathrm{Tg}=$ $2701 \pm 238.7$ by unpaired $t$-test $\mathrm{df}=11 \mathrm{t}=1.862 \mathrm{p}=$ n.s., Fig. $3 \mathrm{H}$.)

\subsection{Inhibition of soluble TNF increases the naive T cell populations in the DCLNs of Tg mice}

In mice treated with XPro1595 between 5 and 7 months of age in Tg mice, no significant changes were seen in the number of total $\mathrm{CD}^{+}{ }^{+}$or $\mathrm{CD} 4^{+} \mathrm{T}$ cells in $\mathrm{DCLN}\left(\mathrm{CD} 4^{+} \mathrm{T}\right.$ cell count - non- $\mathrm{Tg}=43.112 \pm 8847 \mathrm{Tg}=100.768 \pm 29,891$ by unpaired $t$-test $\mathrm{df}=16 \mathrm{t}=1.670$ $\mathrm{p}=$ n.s. Fig. $4 \mathrm{~A} ; \mathrm{CD}^{+} \mathrm{T}$ cell count - non- $\mathrm{Tg}=43,901 \pm 10,246 \mathrm{Tg}=71.747 \pm 17,832$ by unpaired $t$-test $\mathrm{df}=15 \mathrm{t}=1.308 \mathrm{p}=$ n.s., Fig. 4D); however, within the $\mathrm{CD} 4^{+}$and $\mathrm{CD} 8^{+}$ populations, there were significant changes in the effector and naïve populations. Within the $\mathrm{CD}^{+} \mathrm{T}$ cells, there was a trend for an increase in the frequency and a significant increase in the number of naïve $\mathrm{T}$ cells in in XPro1595-treated Tg mice (CD4+ naïve frequency - non$\mathrm{Tg}=46.01 \pm 5.005 \% \mathrm{Tg}=61.00 \pm 5.962 \%$ by unpaired $t$-test $\mathrm{df}=13 \mathrm{t}=1.940 \mathrm{p}=\mathrm{n}$.s.; $\mathrm{CD}^{+}$naïve count - non- $\mathrm{Tg}=18.548 \pm 4598 \mathrm{Tg}=73.129 \pm 23,124$ by unpaired $t$-test $\mathrm{df}=$ $13 \mathrm{t}=2.473 \mathrm{p}<0.05$, Fig. 4B); however, no significant changes were found in the CD4 ${ }^{+}$ effector $\mathrm{T}$ cells $\left(\mathrm{CD} 4^{+}\right.$effector Frequency - non- $\mathrm{Tg}=42.36 \pm 5.331 \% \mathrm{Tg}=27.46 \pm 6.335 \%$ by unpaired $t$-test $\mathrm{df}=13 \mathrm{t}=1.814 \mathrm{p}=$ n.s.; $\mathrm{CD}^{+}$effector count - non- $\mathrm{Tg}=17.979 \pm 4168$ $\mathrm{Tg}=24.819 \pm 10,240$ by unpaired $t$-test $\mathrm{df}=16 \mathrm{t}=0.5654 \mathrm{p}=$ n.s., Fig. 4C). Within the $\mathrm{CD} 8^{+} \mathrm{T}$ cells, there was a significant increase in the frequency and number of naïve $\mathrm{T}$ cells $\left(\mathrm{CD}^{+}\right.$naïve frequency - non- $\mathrm{Tg}=46.35 \pm 5.793 \% \mathrm{Tg}=65.76 \pm 6.619 \%$ by unpaired $t$-test $\mathrm{df}=13 \mathrm{t}=2.217 \mathrm{p}<0.05 ; \mathrm{CD}^{+}$naïve count - non- $\mathrm{Tg}=19.948 \pm 5588 \mathrm{Tg}=80.549$ $\pm 28,025$ by unpaired $t$-test $\mathrm{df}=13 \mathrm{t}=2.265 \mathrm{p}<0.05$, Fig. 4E) and a significant decrease in the frequency, but not number, of effector $\mathrm{T}$ cells $\left(\mathrm{CD}^{+}\right.$effector frequency - non- $\mathrm{Tg}=42.73$ $\pm 5.339 \% \mathrm{Tg}=22.07 \pm 5.048 \%$ by unpaired $t$-test $\mathrm{df}=13 \mathrm{t}=2.787 \mathrm{p}<0.05 ; \mathrm{CD}^{+}$effector count - non- $\mathrm{Tg}=18.953 \pm 5212 \mathrm{Tg}=14.172 \pm 4231$ by unpaired $t$-test $\mathrm{df}=12 \mathrm{t}=0.6760 \mathrm{p}$ $=$ n.s., Fig. $4 \mathrm{~F})$.

When dosed from 2 to 4 months of age, Tg mice showed an increase in the frequency, but not number, of $\mathrm{CD} 8^{+} \mathrm{T}$ cells and decrease in the frequency, but not number, of $\mathrm{CD} 4^{+} \mathrm{T}$ cells $\left(\mathrm{CD} 8^{+}\right.$frequency - non- $\mathrm{Tg}=36.88 \pm 3.110 \% \mathrm{Tg}=44.69 \pm 1.444 \%$ by unpaired $t$-test $\mathrm{df}=$ $13 \mathrm{t}=2.169 \mathrm{p}<0.05 ; \mathrm{CD}^{+}$frequency - non $-\mathrm{Tg}=54.91 \pm 2.134 \% \mathrm{Tg}=47.60 \pm 1.588 \%$ by unpaired $t$-test $\mathrm{df}=13 \mathrm{t}=2.681 \mathrm{p}<0.05)$. Within the $\mathrm{CD} 4^{+} \mathrm{T}$ cell population there were no changes in measured subpopulations, however there was a trend for increased frequency of $\mathrm{CD} 8^{+}$central memory $\mathrm{T}$ cells $\left(\mathrm{CD} 8^{+}\right.$central memory frequency - non- $\mathrm{Tg}=4.326$ $\pm 0.3614 \% \mathrm{Tg}=6.817 \pm 1.296 \%$ by unpaired $t$-test $\mathrm{df}=13 \mathrm{t}=1.966 \mathrm{p}<0.05)$. 


\subsection{Inhibition of soluble TNF decreases amyloid $\beta$ and cytokine expression in the hippocampus of Tg mice}

Inhibition of sTNF significantly decreased the density ( $\%$ of area) of amyloid- $\beta$ in the subiculum, but not the entire hippocampus, of Tg mice (Subiculum - Tg Saline $=57.92$ $\pm 1.736 \% \mathrm{Tg}$ XPro1595 $=51.49 \pm 0.9899 \%$ by unpaired $t$-test $\mathrm{df}=6 \mathrm{t}=3.216 \mathrm{p}<0.05$; Hippocampus $-\mathrm{Tg}$ Saline $=27.67 \pm 1.556 \% \mathrm{TgXPro} 1595=26.51 \pm 1.543 \%$ by unpaired $t$ test $\mathrm{df}=6 \mathrm{t}=0.5296 \mathrm{p}=$ n.s., Fig. 5A). Specifically, within the subiculum, there was a significant decrease in amyloid- $\beta$ density in the dorsal and posterior subiculum (when the dorsal and ventral subiculum come together anatomically) but not the ventral subiculum (Dorsal Subiculum $-\mathrm{Tg}$ Saline $=69.83 \pm 2.197 \% \mathrm{Tg}$ XPro1595 $=63.32 \pm 1.438 \%$ by unpaired $t$-test $\mathrm{df}=6 \mathrm{t}=2.481 \mathrm{p}<0.05$., Fig. 5A; Ventral Subiculum $-\mathrm{Tg}$ Saline $=37.76$ $\pm 1.730 \% \mathrm{Tg}$ XPro1595 $=32.16 \pm 2.951 \%$ by unpaired $t$-test $\mathrm{df}=6 \mathrm{t}=1.897 \mathrm{p}=$ n.s., Fig. $5 \mathrm{~A}$; Posterior Subiculum $-\mathrm{Tg}$ Saline $=56.10 \pm 2.159 \%$ Tg Xpro1595 $=47.93 \pm 1.178 \%$ by unpaired $t$-test $\mathrm{df}=6 \mathrm{t}=3.322 \mathrm{p}<0.05$, data not shown). No significant changes were seen in the hippocampus or subiculum in the density of amino cupric silver stain which denotes disintegration of multiple neuronal elements including cell bodies, axons, dendrites, and synaptic terminals (Hippocampus - Tg Saline $=34.52 \pm 1.348 \%$ Tg XPro1595 $=31.68$ $\pm 2.370 \%$ by unpaired $t$-test $\mathrm{df}=6 \mathrm{t}=1.037 \mathrm{p}=$ n.s., Fig. $5 \mathrm{~B}$; Subiculum $-\mathrm{Tg}$ Saline $=$ $60.96 \pm 1.873 \% \mathrm{Tg}$ XPro1595 $=57.18 \pm 1.816 \%$ by unpaired $t$-test $\mathrm{df}=6 \mathrm{t}=1.450 \mathrm{p}=$ n.s., Fig. 5B; Dorsal Subiculum - Tg Saline $=66.11 \pm 1.694 \%$ Tg XPro1595 $=62.45 \pm 1.734 \%$ by unpaired $t$-test $\mathrm{df}=6 \mathrm{t}=1.509 \mathrm{p}=$ n.s., Fig. 5B; Ventral Subiculum $-\mathrm{Tg}$ Saline $=52.72$ $\pm 3.214 \% \mathrm{Tg}$ XPro1595 $=46.87 \pm 3.022 \%$ by unpaired $t$-test $\mathrm{df}=6 \mathrm{t}=1.325 \mathrm{p}=$ n.s., Fig. 5B; Posterior Subiculum - Tg Saline $=61.49 \pm 1.689 \%$ Tg XPro1595 $=57.50 \pm 1.381 \%$ by unpaired $t$-test $\mathrm{df}=6 \mathrm{t}=1.831 \mathrm{p}=$ n.s., data not shown).

When the contralateral hemisphere was used to measure transcriptional changes in gene expression, gene expression associated with an inflammatory response and its resolution was found to be reduced by inhibition of sTNF with XPro1595. TGF $\beta$ and CCL2 mRNA expression was significantly reduced in $\mathrm{Tg}$ mice, but not non- $\mathrm{Tg}$ mice, treated with XPro1595 from between 5 and 7 months of age. (CCL2 Tg saline $=6.713 \pm 1.170 \mathrm{Tg}$ XPro1595 $=4.055 \pm 0.953$ by 2-way ANOVA $\mathrm{df}=18 \mathrm{t}=2.858 \mathrm{p}<0.05 ; \mathrm{TGF} \beta \mathrm{Tg}$ saline $=$ $3.255 \pm 0.257 \mathrm{Tg}$ XPro1595 $=2.547 \pm 0.201$ by 2 -way ANOVA $\mathrm{df}=18 \mathrm{t}=4.624 \mathrm{p}<0.01$, Table 2, Fig. 5C).

\subsection{XPro1595 blocked LTP deficits in 5XFAD mice}

Deficits in hippocampal CA1 synaptic function have been reported in several mouse models of $\mathrm{AD}$ and are associated with cognitive deficits. To determine if in vivo peripheral administration of XPro1595 modulates synaptic function in Tg mice, brain slices were harvested for analysis of CA3-CA1 synaptic strength curves (Fig. 6A-B) and LTP levels (Fig. 6F-H). At four months of age, basal synaptic strength deficits were found to be relatively mild in vehicle-treated $\mathrm{Tg}$ mice, characterized by a modest downward shift in the synaptic strength curve and a significant reduction $(\mathrm{p}<0.05)$ in the maximal EPSP/FV ratio, relative to non-Tg vehicle-treated mice (Fig. 6C). XPro1595 had minimal effect on synaptic strength (Fig. 6A-B), though it did slightly reduce and slightly increase the maximal EPSP/FV ratio in non-Tg and Tg mice, respectively (Fig. 6C). No genotype or XPro1595 
treatment effects were observed for PPF measures or population spike threshold (Fig. 6DE). LTP was induced in area CA1 using two $100 \mathrm{~Hz}$-stimulus trains (one second duration) separated by $10 \mathrm{~s}$. Consistent with PPF measures, post-tetanic EPSP values during the 5-10 min period after $100 \mathrm{~Hz}$ stimulation was similar across genotypes, indicating the absence of pre-synaptic deficits in 5xFAD mice at this age. However, relative to vehicle-treated non- $\mathrm{Tg}$ mice, the Tg group showed a significant reduction in LTP levels at 60 min post- $100 \mathrm{~Hz}$ stimulation $(153.3 \pm 9.5 \%$ vs $125.3 \pm 5.7 \%, \mathrm{p}<0.05)$ that was blocked by in vivo treatment with XPro1595 (158.2 $\pm 5.1 \%, \mathrm{p}<0.05$ vs Tg vehicle group) (Fig. 6G). In contrast, XPro1595 had minimal effect on LTP in non-Tg mice (141.4 $\pm 15.7 \%$, Fig. $6 \mathrm{H})$. Together, these results demonstrate that XPro1595 protects against age-dependent LTP deficits in Tg mice and does not disrupt LTP mechanisms in non-Tg mice.

\section{Discussion}

Chronic inflammation induced by metabolic syndrome and obesity is associated with increased risk for $\mathrm{AD}$ and may accelerate disease progression. While chronic antiinflammatory usage has been associated epidemiologically with lower incidence of $\mathrm{AD}$, global targeting of inflammatory pathways in clinical trials has had limited success in slowing cognitive decline, either because the targets are wrong or the intervention too late (McGeer and McGeer, 2007) Yet, global immuno-suppression is not likely to be a viable therapeutic strategy to treat neuroinflammation in AD. Our data support specific targeting of sTNF/TNFR1 signaling in regulating alterations in immune cell populations associated with AD-like synaptic deficits (Fig. 7). Specifically, Tg mice develop an age-dependent proinflammatory environment within the brain without evidence of robust CSF or peripheral inflammation; therefore, alterations observed in peripheral immune cells are in response solely to changes in brain inflammation and not additional peripheral inflammatory signals. Immune cells in $\mathrm{Tg}$ mouse brain display changes suggestive of altered communication between the innate and adaptive immune system arms. These observed changes appear at different ages suggesting these trafficking populations may play specific roles at specific points during the progression of the AD-like phenotype. As evidenced by a significant decrease in TGF $\beta$ and CCL2 mRNA in hippocampus, this inflammation is partially mitigated by inhibition of sTNF (Table 2). Decreased CCL2 mRNA suggests that recruitment of peripheral immune cells is dampened with inhibition of sTNF. Decreased TFGb mRNA suggests TGFb-dependent regulation of inflammation is no longer occurring with sTNF inhibition. This selective response may be attributed to multiple inflammatory pathways also regulating expression of multiple inflammatory factors. Moreover, A $\beta$ load in the subiculum and hippocampal LTP impairment are mitigated with in vivo treatment of XPro1595 in association with changes in brain and draining DCLNs.

The increase in cytokines in response to ongoing AD-like pathology at 6 and 7 months suggests that peripheral immune cells may be actively recruited to the pro-inflammatory environment of the brain in Tg mice, implicating the peripheral immune system in modulating progression of AD-like pathology. In support of this, studies have shown that the trafficking of peripheral macrophages to the CNS is necessary for mitigating plaque burden (El Khoury et al., 2007). However, a recent study reported that recruitment of peripheral macrophages is not sufficient to clear accumulated plaque (Varvel et al., 2015). Taken 
together, these data suggest the CNS resident microglia must be working in concert with peripheral immune cells to combat the accumulation of aggregated $A \beta$ and in modulating synaptic function.

Our findings revealed alteration in CNS recruitment and activation status of peripheral immune cells either before or after they enter the brain parenchyma. Within the myeloid compartment of the innate immune system, overall changes in the frequency of $\mathrm{CD} 45^{\text {high }} \mathrm{CD} 11 \mathrm{~b}^{+}$cells, a population that contains peripheral immune cells as well as activated microglia, was not increased in $\mathrm{Tg}$ mice with age. Here we surveyed total brain populations thus suggesting that while globally there are not changes in the $\mathrm{CD} 45^{\text {high }} \mathrm{CD} 11 \mathrm{~b}^{+}$cell population that there may be regional changes that associated with increased pathology or response to experimental treatments. Inhibition of sTNF increased the frequency of $\mathrm{CD} 11 \mathrm{~b}^{+} \mathrm{CD} 11 \mathrm{c}^{+}$population in Tg mice. CD11c is used as a marker of dendritic cells, however a population of $\mathrm{CD} 11 \mathrm{~b}^{+} \mathrm{CD} 11 \mathrm{c}^{+}$cells within the brain parenchyma have been shown to display a microglial, rather than dendric cell, phenotype based on surface marker expression as well as morphology (Dando et al., 2016). This population has been shown to expand in response to neuroinflammation and while increasing levels of MHCII equivalent to blood derived CD $11 \mathrm{c}^{+}$cells, express a different cytokine profile (Wlodarczyk et al., 2014). CD11 $\mathrm{c}^{+}$microglia that accumulate around amyloid plaques show increased anti-inflammatory genomic expression as compared to $\mathrm{CD} 11 \mathrm{c}^{-}$microglia (Kamphuis et al., 2016). The increase in $\mathrm{CD} 11 \mathrm{~b}^{+} \mathrm{CD} 11 \mathrm{c}^{+}$cells could thus be interpreted as an increased in $\mathrm{CD}_{1} 1 \mathrm{c}^{+}$microglia that preform a specific anti-inflammatory function within the inflamed brain. Our data revealed changes in activation status of recruited cells, high expression of Ly6C correlates with expression of CCR2 and higher capacity for phagocytosis while Ly6C ${ }^{\text {low }}$ expression correlates with expression of CX3CR1 and antiinflammatory actions (Yang et al., 2014). The ratio of Ly6C expression can reveal shifts in the activation status of macrophage populations towards pro-inflammatory, phagocytic activation (higher ratio) or towards alternative anti-inflammatory activation (lower ratio). Our data indicated the ratio of $\mathrm{CD} 11 \mathrm{~b}^{+} \mathrm{Ly} 6 \mathrm{C}^{\text {high }}$ to $\mathrm{Ly} 6 \mathrm{C}^{\text {low }}$ had shifted in $\mathrm{Tg}$ mice towards more Ly6Chigh cells. These changes in Ly6C suggest that the Ly6C ${ }^{+} \mathrm{CD} 11 \mathrm{~b}^{+}$myeloid cells in the CNS of Tg mice, potentially infiltrating macrophages, may be more active than the infiltrating macrophages in non-Tg CNS. This may be an adaptive response to combat plaque accumulation, however peripheral macrophages from AD patients are less phagocytic as compared to healthy controls (Fiala et al., 2005), suggesting the phagocytic capabilities of these cells may be impeded.

A recent study reported in 5xFADxRAG mice lacking functional $\mathrm{T}$ cells, $\mathrm{B}$ cells, and some NK cells significantly increased amyloid $\beta$ load, indicating that the adaptive immune system plays a key role in mitigating AD-like pathology (Marsh et al., 2016). In agreement with others (Bryson and Lynch, 2015), we found increased numbers of T cells in the brains of $\mathrm{Tg}$ mice at later stages. Specifically, we found increased $\mathrm{CD} 8^{+} \mathrm{T}$ cells but not $\mathrm{CD} 4^{+} \mathrm{T}$ cells. The frequency of $\mathrm{CD}^{+}$effector T cells is decreased in Tg mice at 3.5 months, without a change in number of $\mathrm{CD}^{+}$effector T cells, suggesting subtle changes in $\mathrm{CD}^{+}$naïve and memory subsets has decreased the proportion of $\mathrm{CD}^{+} \mathrm{T}$ cells that are effectors. At the following time point the decrease in $\mathrm{CD}^{+}$effector $\mathrm{T}$ cells is no long seen in $\mathrm{Tg}$ mice, due to a significant increase in the number of $\mathrm{CD}^{+}$effector $\mathrm{T}$ cells. This response maybe an 
adaptive response to the change in frequency seen at the earlier time-point to return the frequency distribution of $\mathrm{CD} 8^{+} \mathrm{T}$ cell subsets to a homeostatic level seen in non-Tg mice. Cytotoxic $\mathrm{CD} 8^{+} \mathrm{T}$ cells are increased in the $\mathrm{AD}$ brain and likely have negative consequences for neuronal function and integrity (Togo et al., 2002). While CD8 ${ }^{+}$effector cells were not decreased in the brain with STNF inhibition (potentially because the dosed time point is earlier than when we see significant differences in $\mathrm{CD} 8^{+} \mathrm{T}$ cells), the $\mathrm{CD} 3^{+} \mathrm{T}$ cell population was decreased due to a significantly decreased $\mathrm{CD} 4^{+} \mathrm{T}$ cell subpopulation and is likely to be due to a trend in decreased $\mathrm{CD} 4^{+}$effector cells. Effector $\mathrm{CD} 4^{+} \mathrm{T}$ cells functions range from prionflammatory to regulatory, which may have very different consequences on AD-like pathology, specific regulation of $\mathrm{T}$ cell subsets has therapeutic potential yet the role of these subsets in $\mathrm{AD}$ needs further investigation.

Our findings also shed light on the potential role for antigen presentation in progression of AD-like pathology. Major histocompatibility complex II (MHCII) is used by antigen presenting cells (APCs), such as microglia and macrophage, to activate $\mathrm{CD} 4^{+} \mathrm{T}$ cells in an antigen specific manner. MHCII is important for crosstalk between the innate and adaptive immune systems and for presentation of antigens to activate $\mathrm{CD}^{+} \mathrm{T}$ cells (Neefjes et al., 2011). Decreases in MHCII frequency may suggest that cross talk between APCs and T cells is diminished and $\mathrm{CD} 4^{+} \mathrm{T}$ cell activation is decreased. We show that $\mathrm{Tg}$ mice have decreased frequency of $\mathrm{CD} 11 \mathrm{~b}^{+} \mathrm{CD} 45^{\text {high }} \mathrm{MHCII}^{+}$brain immune cells. This is contrary to reports of increased MHCII reactivity around plaques in the human AD brain (Perlmutter et al., 1992). It is important to note, however, that animal models do not fully recapitulate human disease and in particular, our data were not derived from the most advanced stages of AD-like pathology in $\mathrm{Tg}$ mice levels of $\mathrm{MHCII}^{+}$cells in the brain measured by flow cytometry reflect the net levels in the brain and region-specific differences certainly exist which can only be accurately captured using immunohistological approaches. Specifically, it is possible that $\mathrm{MHCII}^{+}$cells are enriched around amyloid plaques while across the brain there may be overall decreases in the total $\mathrm{CD}_{11} \mathrm{~b}^{+}-\mathrm{CD} 45^{\text {high }} \mathrm{MHCII}^{+}$population. Importantly, across all $\mathrm{CD}_{11} \mathrm{~b}^{+}$cells, there were no effects of genotype on MHCII expression only within this particular subset of CD45 ${ }^{\text {high }}$ cells that contains peripheral macro-phages as well as activated microglia. Therefore, the decreased MHCII observed in Tg mice suggests that communication and subsequent activation of brain $\mathrm{CD}^{+} \mathrm{T}$ cells by infiltrating macrophages/activated microglia $\left(\mathrm{CD} 11 \mathrm{~b}^{+} \mathrm{CD} 45^{\text {high }}\right)$ is impaired; this may or may not be an adaptive response. $\mathrm{CD} 4^{+} \mathrm{T}$ cells can have both pro-inflammatory and protective regulatory effects (Wan and Flavell, 2009). In our study, we found that primarily effector CD4 ${ }^{+} \mathrm{T}$ cells in the brain, which can be pro-inflammatory or regulatory, were decreased following XPro1595. One subset of $\mathrm{CD} 4^{+}$effector T cells, $\mathrm{CD} 4^{+}$regulator $\mathrm{T}$ cells (Treg), suppressors of immune responses, have been shown to be elevated in elderly populations, and shown to have increased suppressive activity in AD patients (Rosenkranz et al., 2007). In an AD mouse model removal of Treg suppressive effect on the immune system, via transient depletion or inhibition, increased leukocyte trafficking at the choroid plexus, increased brain $\mathrm{CD} 45^{\text {high }} \mathrm{CD} 11 \mathrm{~b}^{+}$and Treg populations, as well as decreased plaque burden, proinflammatory cytokine mRNA expression, and improved on cognitive function (Baruch et al., 2015). Further investigation may reveal changes within effector $\mathrm{CD} 4^{+} \mathrm{T}$ cells, 
specifically Tregs, in the brain and will enhance our understanding of how changes in MHCII contribute to or protect against AD-like pathology.

T cells residing in the DCLNs have the opportunity to encounter antigens and other soluble factors draining from the brain. Our data revealed that $\mathrm{Tg}$ mice have populations of $\mathrm{CD} 4^{+}$ and $\mathrm{CD}^{+} \mathrm{T}$ cells skewed towards significantly more naïve cells and fewer effector cells within the DCLNs. These T cells may then become primed to carry out their functions in the brain. While there were no significant differences in the overall number of T cells, fewer of these were effector cells in the DCLNs of Tg mice, suggesting they may be elsewhere (i.e. in the blood on route to the brain) or alternatively, that there is impaired crosstalk between the innate and adaptive immune system in $\mathrm{Tg}$ mice. The increased population of $\mathrm{CD} 8^{+}$effector cells that we see in the brain of $\mathrm{Tg}$ mice suggests the former; that these cells are trafficking from the DCLN where they may have first been exposed to brain antigen and have now moved into the brain where they will perform their effector functions. In $\mathrm{Tg}$ mice the frequency of $\mathrm{CD}^{+}$and $\mathrm{CD} 8^{+}$effector T cells is decreased in the DCLNs, without corresponding changes in number of $\mathrm{T}$ cell subsets, these results may suggest that the localization of these $\mathrm{T}$ cells is altered by plaque pathology. The $\mathrm{CD} 8^{+}$effector $\mathrm{T}$ cell population is increased in the brain at 5 months of age suggesting that there may be increased trafficking from the DCLNs to the brain in Tg mice. Future studies will explore the soluble factors (including amyloid $\beta$ ) within the DCLNs that may be activating these $\mathrm{T}$ cells. With inhibition of sTNF, we observe an increased number of naïve $\mathrm{CD} 4^{+}$and $\mathrm{CD} 8^{+} \mathrm{T}$ cells within the DCLN. Despite the fact that we observe no change in the number of effector $\mathrm{T}$ cells within the DCLNs following sTNF inhibition, the cells within this population may be changed in function, given that STNF can act as a regulator of effector $\mathrm{T}$ cell activation (Evangelidou et al., 2010). This and other possibilities will be explored in future studies that assess the profile of secreted cytokines along with histological markers of tissue inflammation.

The changes we observed in T cell profiles in the DCLNs and in immune cell profiles in the brain following XPro1595 are most likely due to direct inactivation of sTNF/TNFR1 signaling on immune cells. sTNF is an inflammatory mediator of BBB permeability activating cells along brain capillaries, leading to up-regulation of factors that facilitate immune cell entry across the BBB (Nadeau and Rivest, 1999; Rezai-Zadeh et al., 2009). Regulation of downstream factors of sTNF/TNFR1 signaling, such as Lipocalin 2 (Lcn2), may also be contributing to effects seen by XPro1595. Lcn2 expression is significantly increased in the AD brain, has been shown to impair neuroprotective TNFR2 signaling, and increase A $\beta$ toxicity (Naude et al., 2012). As a measurement of pathology outcome we also measured amyloid plaque via IHC. We found a small, yet significant decrease in amyloid (6E10) density indicating that sTNF may play a role in the production or accumulation of amyloid pathology. Further investigation of the roll of soluble TNF inhibition on the mechanisms of plaque accumulation may be warranted based upon this data.

Finally, the most promising finding in our study is the ability of XPro1595 to restore LTP in $\mathrm{Tg}$ mice because it is clear that synaptic dysfunction is responsible for memory deficits and cognitive decline in AD. Future studies will be aimed at determining the extent to which the restoration of LTP resulting from sTNF signaling inhibition was due to decreased amyloid 
deposition in the hippocampus or via direct effect on synaptic physiology. However, given that TNF can inhibit LTP (Cunningham et al., 1996) and that sTNF promotes long-term depression (LTD) in aged rats (Sama et al., 2012), our findings with XPro1595 in 5xFAD mice strongly suggest that sTNF is likely to be directly mediating the LTP deficits in Tg mice. sTNF has been shown to play an important role in potentiating glutamate excitotoxicity, through direction activation of NMDA receptors and increasing AMPA receptor localization at the synapse, while transmembrane TNF/TNFR2 signaling has been implicated in protection against excitotoxicity (McCoy and Tansey, 2008). Inhibition of sTNF via XPro1595 may be modulating these direct mechanisms of sTNF at the synapse as well as modulating BBB permeability and immune cell activation. Further investigation may reveal that modulating these multiple mechanisms of sTNF may be contributing to the overall effects on LTP and immune cell trafficking. Our group has shown that peripherally administered XPro1595 gets across the BBB and is able to sequester the picomolar levels of sTNF within the brain (Barnum et al., 2014); however, a recent clinical study with a nonBBB crossing TNF inhibitor (etanercept), implicates a TNF-dependent peripheral mechanisms in the cognitive decline associated with $\mathrm{AD}$ pathogenesis (Butchart et al., 2015). Together, these data suggest that TNF can have both direct effects on synaptic physiology as well as indirect effects on peripheral cytokines and immune cell traffic to the CNS and brain resident immune cells and thus, targeting sTNF centrally and peripherally may afford added advantage to improve functional outcomes in patients with AD.

\section{Supplementary Material}

Refer to Web version on PubMed Central for supplementary material.

\section{Acknowledgments}

We thank members of the Tansey lab for useful discussions. We also thank David Szymkowski at Xencor Inc. for providing XPro1595, Robert Vassar at Northwestern for providing 5xFAD mice, and NeuroScience Associates for technical assistance with immunohistochemistry. Funding support from: This study was supported in part by the Emory ADRC P50 AG025688, the Alzheimer's Drug Discovery Foundation (MGT), NIA/NIH 1RF1AG051514-01 (MGT), a pre-doctoral training grant in translational research in neurology 5 T32 NS007480-14 (KPM), and the Emory Multiplexed Immunoassay Core (EMIC), which is subsidized by the Emory University School of Medicine and is one of the Emory Integrated Core Facilities. Additional support was provided by the National Center for Advancing Translational Sciences of the National Institutes of Health under Award Number UL1TR000454. The content is solely the responsibility of the authors and does not necessarily reflect the official views of the National Institutes of Health.

\section{References}

Akiyama H, Barger S, Barnum S, Bradt B, Bauer J, Cole G, Cooper N, Eikelenboom P, Emmerling M, Fiebich B, Finch C, Frautschy S, Griffin W, Hampel H, Hull M, Landreth G, Lue L, Mrak R, Mackenzie I, McGeer P, O’Banion M, Pachter J, Pasinetti G, Plata-Salaman C, Rogers J, Rydel R, Shen Y, Streit W, Strohmeyer R, Tooyoma I, Van Muiswinkel F, Veerhuis R, Walker D, Webster S, Wegrzyniak B, Wenk G, Wyss-Coray T. Inflammation and Alzheimer's disease. Neurobiol Aging. 2000; 21(3):383-421. [PubMed: 10858586]

Aspelund A, Antila S, Proulx ST, Karlsen TV, Karaman S, Detmar M, Wiig H, Alitalo K. A dural lymphatic vascular system that drains brain interstitial fluid and macromolecules. J Exp Med. 2015; 212(7):991-999. [PubMed: 26077718]

Bachstetter AD, Norris CM, Sompol P, Wilcock DM, Goulding D, Neltner JH, St Clair D, Watterson DM, Van Eldik LJ. Early stage drug treatment that normalizes proinflammatory cytokine production attenuates synaptic dysfunction in a mouse model that exhibits age-dependent progression of 
Alzheimer's disease-related pathology. J Neurosci. 2012; 32(30):10201-10210. [PubMed: 22836255]

Barnum CJ, Chen X, Chung J, Chang J, Williams M, Grigoryan N, Tesi RJ, Tansey MG. Peripheral administration of the selective inhibitor of soluble tumor necrosis factor (TNF) XPro(R)1595 attenuates nigral cell loss and glial activation in 6-OHDA hemiparkinsonian rats. J Parkinsons Dis. 2014; 4(3):349-360. [PubMed: 25061061]

Baruch K, Rosenzweig N, Kertser A, Deczkowska A, Sharif AM, Spinrad A, Tsitsou-Kampeli A, Sarel A, Cahalon L, Schwartz M. Breaking immune tolerance by targeting Foxp3(+) regulatory T cells mitigates Alzheimer's disease pathology. Nat Commun. 2015; 6:7967. [PubMed: 26284939]

Brambilla R, Ashbaugh J, Magliozzi R, Dellarole A, Karmally S, Szymkowski D, Bethea J. Inhibition of soluble tumour necrosis factor is therapeutic in experimental autoimmune encephalomyelitis and promotes axon preservation and remyelination. Brain. 2011; 134(Pt 9):2736-2754. [PubMed: 21908877]

Brosseron F, Krauthausen M, Kummer M, Heneka MT. Body fluid cytokine levels in mild cognitive impairment and Alzheimer's disease: a comparative over-view. Mol Neurobiol. 2014; 50(2):534544. [PubMed: 24567119]

Bryson KJ, Lynch Ma. Linking T cells to Alzheimer's disease: from neurodegeneration to neurorepair. Curr Opin Pharmacol. 2015; 26:67-73. [PubMed: 26516722]

Butchart J, Brook L, Hopkins V, Teeling J, Puntener U, Culliford D, Sharples R, Sharif S, McFarlane B, Raybould R, Thomas R, Passmore P, Perry VH, Holmes C. Etanercept in Alzheimer disease: a randomized, placebo-controlled, double-blind, phase 2 trial. Neurology. 2015; 84(21):2161-2168. [PubMed: 25934853]

Cunningham AJ, Murray Ca, O’Neill LA, Lynch Ma, O'Connor JJ. Interleukin-1 beta (IL-1 beta) and tumour necrosis factor (TNF) inhibit long-term potentiation in the rat dentate gyrus in vitro. Neurosci Lett. 1996; 203(1):17-20. [PubMed: 8742036]

Dando SJ, Naranjo Golborne C, Chinnery HR, Ruitenberg MJ, McMenamin PG. A case of mistaken identity: CD11c-eYFP(+) cells in the normal mouse brain parenchyma and neural retina display the phenotype of microglia, not dendritic cells. Glia. 2016; 64(8):1331-1349. [PubMed: 27189804]

El Khoury J, Toft M, Hickman SE, Means TK, Terada K, Geula C, Luster AD. Ccr2 deficiency impairs microglial accumulation and accelerates progression of Alzheimer-like disease. Nat Med. 2007; 13(4):432-438. [PubMed: 17351623]

Evangelidou M, Tseveleki V, Vamvakas SS, Probert L. TNFRI is a positive T-cell costimulatory molecule important for the timing of cytokine responses. Immunol Cell Biol. 2010; 88(5):586595. [PubMed: 20212506]

Fiala M, Lin J, Ringman J, Kermani-Arab V, Tsao G, Patel A, Lossinsky AS, Graves MC, Gustavson A, Sayre J, Sofroni E, Suarez T, Chiappelli F, Bernard G. In-effective phagocytosis of amyloidbeta by macrophages of Alzheimer's disease patients. J Alzheimers Dis. 2005; 7(3):221-232. discussion 255-262. [PubMed: 16006665]

Furman JL, Sama DM, Gant JC, Beckett TL, Murphy MP, Bachstetter AD, Van Eldik LJ, Norris CM. Targeting astrocytes ameliorates neurologic changes in a mouse model of Alzheimer's disease. J Neurosci. 2012; 32(46):16129-16140. [PubMed: 23152597]

Heneka MT, Carson MJ, El Khoury J, Landreth GE, Brosseron F, Feinstein DL, Jacobs AH, WyssCoray T, Vitorica J, Ransohoff RM, Herrup K, Frautschy SA, Finsen B, Brown GC, Verkhratsky A, Yamanaka K, Koistinaho J, Latz E, Halle A, Petzold GC, Town T, Morgan D, Shinohara ML, Perry VH, Holmes C, Bazan NG, Brooks DJ, Hunot S, Joseph B, Deigendesch N, Garaschuk O, Boddeke E, Dinarello CA, Breitner JC, Cole GM, Golenbock DT, Kummer MP. Neuroinflammation in Alzheimer's disease. Lancet Neurol. 2015; 14(4):388-405. [PubMed: 25792098]

Hickman SE, El Khoury J. Mechanisms of mononuclear phagocyte recruitment in Alzheimer's disease. CNS Neurol Disord Drug Targets. 2010; 9(2):168-173. [PubMed: 20205643]

Holmes C, Cunningham C, Zotova E, Woolford J, Dean C, Kerr S, Culliford D, Perry V. Systemic inflammation and disease progression in Alzheimer disease. Neurology. 2009; 73(10):768-774. [PubMed: 19738171] 
Kamphuis W, Kooijman L, Schetters S, Orre M, Hol EM. Transcriptional profiling of CD11c-positive microglia accumulating around amyloid plaques in a mouse model for Alzheimer's disease. Biochim Biophys Acta. 2016; 1862(10):1847-1860. [PubMed: 27425031]

Kannarkat GT, Lee JK, Ramsey CP, Chung J, Chang J, Porter I, Oliver D, Shepherd K, Tansey MG. Age-related changes in regulator of G-protein signaling (RGS)-10 expression in peripheral and central immune cells may influence the risk for age-related degeneration. Neurobiol Aging. 2015; 36(5):1982-1993. [PubMed: 25784210]

Laman JD, Weller RO. Drainage of cells and soluble antigen from the CNS to regional lymph nodes. J NeuroImmune Pharmacol. 2013; 8(4):840-856. [PubMed: 23695293]

Louveau A, Smirnov I, Keyes TJ, Eccles JD, Rouhani SJ, Peske JD, Derecki NC, Castle D, Mandell JW, Lee KS, Harris TH, Kipnis J. Structural and functional features of central nervous system lymphatic vessels. Nature. 2015; 523(7560):337-341. [PubMed: 26030524]

MacEwan DJ. TNF receptor subtype signalling: differences and cellular consequences. Cell Signal. 2002; 14(6):477-492. [PubMed: 11897488]

Mandrekar-Colucci S, Landreth GE. Microglia and inflammation in Alzheimer's disease. CNS Neurol Disord Drug Targets. 2010; 9(2):156-167. [PubMed: 20205644]

Marsh SE, Abud EM, Lakatos A, Karimzadeh A, Yeung ST, Davtyan H, Fote GM, Lau L, Weinger JG, Lane TE, Inlay MA, Poon WW, Blurton-Jones M. The adaptive immune system restrains Alzheimer's disease pathogenesis by modulating microglial function. Proc Natl Acad Sci U S A. 2016; 113(9):E1316-E1325. [PubMed: 26884167]

Mathis DM, Furman JL, Norris CM. Preparation of acute hippocampal slices from rats and transgenic mice for the study of synaptic alterations during aging and amyloid pathology. J Vis Exp. 2011; 49

McAlpine F, Lee JK, Harms A, Ruhn K, Blurton-Jones M, Hong J, Das P, Golde T, LaFerla F, Oddo S, Blesch A, Tansey M. Inhibition of soluble TNF signaling in a mouse model of Alzheimer's disease prevents pre-plaque amyloid-associated neuropathology. Neurobiol Dis. 2009; 34(1):163-177. [PubMed: 19320056]

McCoy M, Tansey M. TNF signaling inhibition in the CNS: implications for normal brain function and neurodegenerative disease. J Neuroinflammation. 2008; 5:45. [PubMed: 18925972]

McCoy M, Martinez T, Ruhn K, Szymkowski D, Smith C, Botterman B, Tansey K, Tansey M. Blocking soluble tumor necrosis factor signaling with dominant-negative tumor necrosis factor inhibitor attenuates loss of dopaminergic neurons in models of Parkinson's disease. J Neurosci. 2006; 26(37):9365-9375. [PubMed: 16971520]

McGeer P, McGeer E. NSAIDs and Alzheimer disease: epidemiological, animal model and clinical studies. Neurobiol Aging. 2007; 28(5):639-647. [PubMed: 16697488]

Montagne A, Barnes SR, Sweeney MD, Halliday MR, Sagare AP, Zhao Z, Toga AW, Jacobs RE, Liu CY, Amezcua L, Harrington MG, Chui HC, Law M, Zlokovic BV. Blood-brain barrier breakdown in the aging human hippocampus. Neuron. 2015; 85(2):296-302. [PubMed: 25611508]

Montgomery SL, Mastrangelo MA, Habib D, Narrow WC, Knowlden SA, Wright TW, Bowers WJ. Ablation of TNF-RI/RII expression in Alzheimer's disease mice leads to an unexpected enhancement of pathology: implications for chronic pan-TNF-alpha suppressive therapeutic strategies in the brain. Am J Pathol. 2011; 179(4):2053-2070. [PubMed: 21835156]

Montgomery SL, Narrow WC, Mastrangelo MA, Olschowka JA, O’Banion MK, Bowers WJ. Chronic neuron- and age-selective down-regulation of TNF receptor expression in triple-transgenic Alzheimer disease mice leads to significant modulation of amyloid- and Tau-related pathologies. Am J Pathol. 2013; 182(6):2285-2297. [PubMed: 23567638]

Nadeau S, Rivest S. Effects of circulating tumor necrosis factor on the neuronal activity and expression of the genes encoding the tumor necrosis factor receptors (p55 and p75) in the rat brain: a view from the blood-brain barrier. Neuroscience. 1999; 93(4):1449-1464. [PubMed: 10501470]

Naude PJ, Nyakas C, Eiden LE, Ait-Ali D, van der Heide R, Engelborghs S, Luiten PG, De Deyn PP, den Boer JA, Eisel UL. Lipocalin 2: novel component of proinflammatory signaling in Alzheimer's disease. FASEB J. 2012; 26(7):2811-2823. [PubMed: 22441986]

Neefjes J, Jongsma ML, Paul P, Bakke O. Towards a systems understanding of MHC class I and MHC class II antigen presentation. Nat Rev Immunol. 2011; 11(12):823-836. [PubMed: 22076556] 
Oakley H, Cole S, Logan S, Maus E, Shao P, Craft J, Guillozet-Bongaarts A, Ohno M, Disterhoft J, Van Eldik L, Berry R, Vassar R. Intraneuronal beta-amyloid aggregates, neurodegeneration, and neuron loss in transgenic mice with five familial Alzheimer's disease mutations: potential factors in amyloid plaque formation. J Neurosci. 2006; 26(40):10129-10140. [PubMed: 17021169]

Perlmutter LS, Scott SA, Barron E, Chui HC. MHC class II-positive microglia in human brain: association with Alzheimer lesions. J Neurosci Res. 1992; 33(4):549-558. [PubMed: 1484388]

Ransohoff RM, Brown MA. Innate immunity in the central nervous system. J Clin Invest. 2012; 122(4):1164-1171. [PubMed: 22466658]

Ransohoff RM, Engelhardt B. The anatomical and cellular basis of immune surveillance in the central nervous system. Nat Rev Immunol. 2012; 12(9):623-635. [PubMed: 22903150]

Rezai-Zadeh K, Gate D, Town T. CNS infiltration of peripheral immune cells: D-Day for neurodegenerative disease? J Neurosci. 2009; 4(4):462-475.

Rochfort KD, Collins LE, Murphy RP, Cummins PM. Downregulation of blood-brain barrier phenotype by proinflammatory cytokines involves NADPH oxidase-dependent ROS generation: consequences for interendothelial adherens and tight junctions. PLoS One. 2014; 9(7):e101815. [PubMed: 24992685]

Rose S, Misharin A, Perlman H. A novel Ly6C/Ly6G-based strategy to analyze the mouse splenic myeloid compartment. Cytometry A. 2012; 81(4):343-350. [PubMed: 22213571]

Rosenkranz D, Weyer S, Tolosa E, Gaenslen A, Berg D, Leyhe T, Gasser T, Stoltze L. Higher frequency of regulatory $\mathrm{T}$ cells in the elderly and increased suppressive activity in neurodegeneration. J Neuroimmunol. 2007; 188(1-2):117-127. [PubMed: 17582512]

Sama DM, Mohmmad Abdul H, Furman JL, Artiushin IA, Szymkowski DE, Scheff SW, Norris CM. Inhibition of soluble tumor necrosis factor ameliorates synaptic alterations and $\mathrm{Ca}^{2+}$ dysregulation in aged rats. PLoS One. 2012; 7(5):e38170. [PubMed: 22666474]

Sedgwick JD, Schwender S, Imrich H, Dorries R, Butcher GW, ter Meulen V. Isolation and direct characterization of resident microglial cells from the normal and inflamed central nervous system. Proc Natl Acad Sci U S A. 1991; 88(16):7438-7442. [PubMed: 1651506]

Steed PM, Tansey MG, Zalevsky J, Zhukovsky EA, Desjarlais JR, Szymkowski DE, Abbott C, Carmichael D, Chan C, Cherry L, Cheung P, Chirino AJ, Chung HH, Doberstein SK, Eivazi A, Filikov AV, Gao SX, Hubert RS, Hwang M, Hyun L, Kashi S, Kim A, Kim E, Kung J, Martinez SP, Muchhal US, Nguyen DH, O’Brien C, O’Keefe D, Singer K, Vafa O, Vielmetter J, Yoder SC, Dahiyat BI. Inactivation of TNF signaling by rationally designed dominant-negative TNF variants. Science. 2003; 301(5641):1895-1898. [PubMed: 14512626]

Steinman L. Inflammatory cytokines at the summits of pathological signal cascades in brain diseases. Sci Signal. 2013; 6(258)

Swardfager W, Lanctot K, Rothenburg L, Wong A, Cappell J, Herrmann N. A meta-analysis of cytokines in Alzheimer's disease. Biol Psychiatry. 2010; 68(10):930-941. [PubMed: 20692646]

Togo T, Akiyama H, Iseki E, Kondo H, Ikeda K, Kato M, Oda T, Tsuchiya K, Kosaka K. Occurrence of T cells in the brain of Alzheimer's disease and other neurological diseases. J Neuroimmunol. 2002; 124(1-2):83-92. [PubMed: 11958825]

Varvel NH, Grathwohl SA, Degenhardt K, Resch C, Bosch A, Jucker M, Neher JJ. Replacement of brain-resident myeloid cells does not alter cerebral amyloid-beta deposition in mouse models of Alzheimer's disease. J Exp Med. 2015; 212(11):1803-1809. [PubMed: 26458770]

Wan YY, Flavell RA. How diverse-CD4 effector T cells and their functions. J Mol Cell Biol. 2009; 1(1):20-36. [PubMed: 19482777]

Wlodarczyk A, Lobner M, Cedile O, Owens T. Comparison of microglia and infiltrating CD11c(+) cells as antigen presenting cells for T cell proliferation and cytokine response. $\mathrm{J}$ Neuroinflammation. 2014; 11:57. [PubMed: 24666681]

Yang J, Zhang L, Yu C, Yang XF, Wang H. Monocyte and macrophage differentiation: circulation inflammatory monocyte as biomarker for inflammatory diseases. Biomark Res. 2014; 2(1):1. [PubMed: 24398220] 
\begin{tabular}{l|l|l}
\hline TNF MRNA CCL2 mRNA & B
\end{tabular}

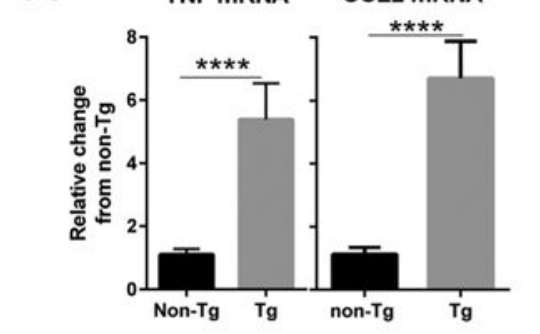

B

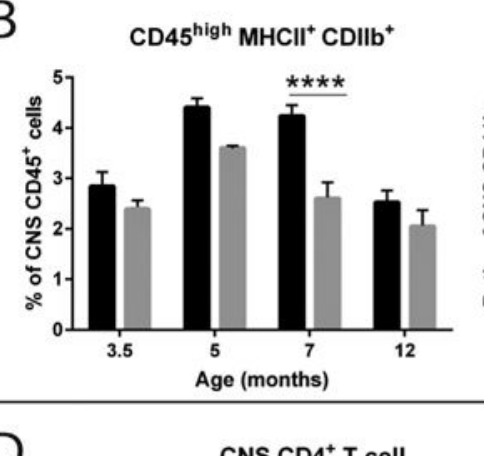

C
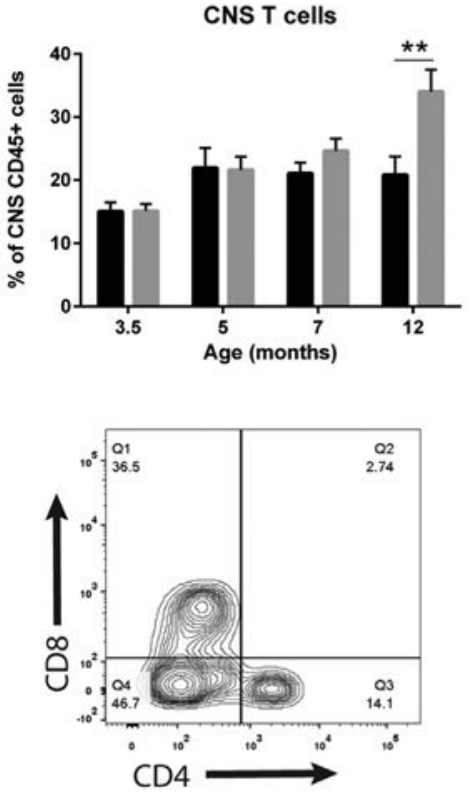
CD8 ${ }^{+}$Effector $\mathrm{T}$ cells
D

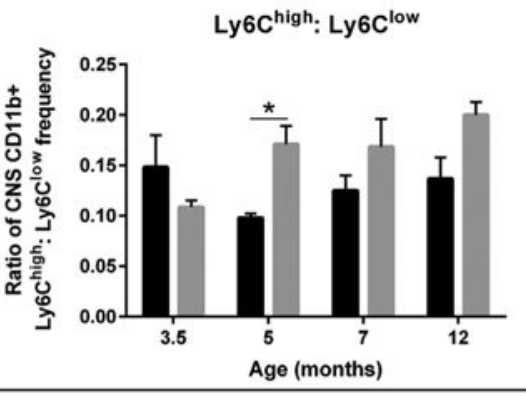

CNS $\mathrm{CDB}^{+} \mathrm{T}$ cells

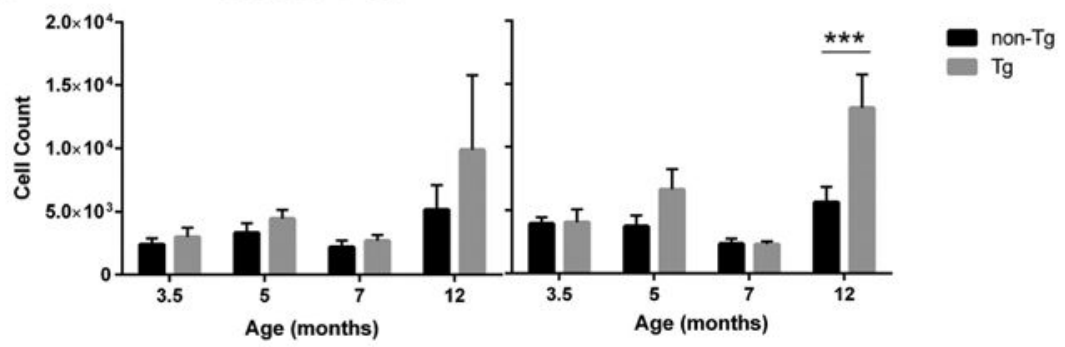

$\mathrm{E}$
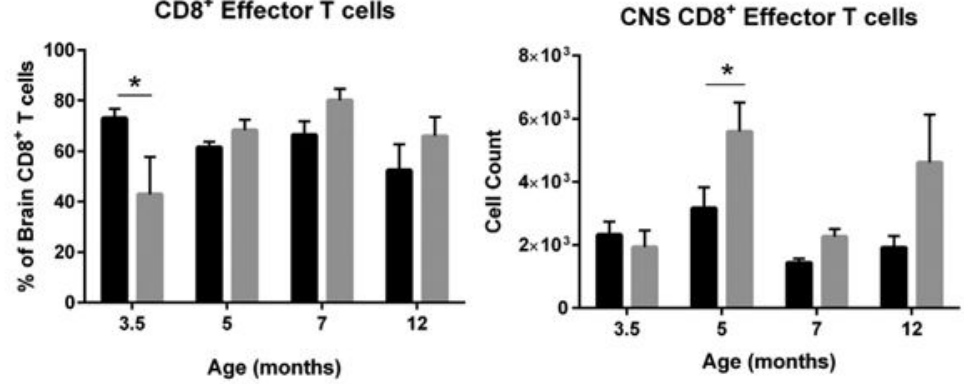

Fig. 1.

Altered peripheral immune cell populations in the pro-inflammatory AD-like brain environment. A) Graphical depiction of select results from Table 2. At 7 months of age CCL2 and TNF mRNA expression is significantly increased in the hippocampus of Tg mice as compared to non-Tg mice. By flow cytometry, populations of immune cells within the brain were measured at $3.5,5,7$, and 12 months of age in non- $\mathrm{Tg}$ and $\mathrm{Tg}$ mice. B) While there are no effects of genotype on frequency or number of $\mathrm{CD}_{11} \mathrm{~b}^{+}$(microglia and macrophage) or $\mathrm{CD} 11 \mathrm{~b}^{+} \mathrm{CD} 45^{\text {high }}$ (peripheral macrophage and activated microglia) immune cells (data not shown), there is a significant decrease in the frequency of $\mathrm{MHCII}^{+} \mathrm{CD} 45^{\text {high }} \mathrm{CD} 11 \mathrm{~b}^{+}$cells in the brain of $\mathrm{Tg}$ mice compared to that in non-Tg mice at 7 months of age, $* * * * \mathrm{p}<0.0001$. At 5 months of age the ratio of Ly6Chigh. $\mathrm{Ly} 6 \mathrm{C}^{\text {low }}$ is significantly increased as compared to non-Tg mice $* p<0.05$. C) At 12 months of age the frequency of $\mathrm{CD}^{+} \mathrm{T}$ cells in significantly increased in $\mathrm{Tg}$ mice as compared to non- $\mathrm{Tg}$ mice, $* * \mathrm{p}<0.01$. Contour plot inset shows CD4 and CD8 gating on the brain $\mathrm{CD}^{+} \mathrm{T}$ cell population. Within this population, subsets of $\mathrm{CD} 4^{+}$and $\mathrm{CD} 8^{+} \mathrm{T}$ cells were measured. D) In both non- $\mathrm{Tg}$ and $\mathrm{Tg}$ mice, the number of $\mathrm{CD}^{+}{ }^{+} \mathrm{T}$ cells increases within the CNS with age. No effects were seen within the $\mathrm{CD} 4^{+} \mathrm{T}$ cell population. In $\mathrm{Tg}$ mice there was a significant 
increase in the number of $\mathrm{CD} 8^{+} \mathrm{T}$ cells within the CNS at 12 months of age, $* * * \mathrm{p}<0.001$. E) Within the $\mathrm{CD}^{+} \mathrm{T}$ cell population, there is a significant decrease in the frequency of $\mathrm{CD}^{+}$effector $\mathrm{T}$ cell $\left(\mathrm{CD}^{2} \mathrm{~L}^{-} \mathrm{CD} 44^{-}\right)$population in $\mathrm{Tg}$ mice as compared to non-Tg mice at 3.5 months of age. By 5 months of age, the frequency of $\mathrm{CD}^{+}$effector cells has increased in $\mathrm{Tg}$ mice to non- $\mathrm{Tg}$ levels. At this same time point, there is a significant increase in the number of $\mathrm{CD}^{+}$effector $\mathrm{T}$ cells within the brain that can account for this return to non- $\mathrm{Tg}$ frequency levels, ${ }^{*} \mathrm{p}<0.05 .3 .5$ months: non- $\operatorname{Tg} \mathrm{n}=8, \operatorname{Tg} \mathrm{n}=9 ; 5$ months: non- $\operatorname{Tg} \mathrm{n}=11$, $\operatorname{Tg} \mathrm{n}=11 ; 7$ months: non- $\operatorname{Tg} \mathrm{n}=11, \operatorname{Tg} \mathrm{n}=13 ; 12$ months: $\operatorname{non}-\operatorname{Tg} \mathrm{n}=10, \operatorname{Tg} \mathrm{n}=9$. Within these groups, subsets with robust MHCII and Ly6C staining were used for analysis of these markers in the brain: 3.5 months: non- $\mathrm{Tg} \mathrm{n}=8$ (MHCII)/5 (Ly6C), $\operatorname{Tg~} \mathrm{n}=9 / 4 ; 5$ months: non- $\operatorname{Tg} n=4 / 7, \operatorname{Tg} n=7 / 8 ; 7$ months: non- $\operatorname{Tg} n=8 / 6, \operatorname{Tg} n=11 / 7 ; 12$ months: non- $\operatorname{Tg} n=$ $9 / 10, \operatorname{Tg} \mathrm{n}=8 / 4$. From the overall group, a subset of samples had reliable CD44 and CD62L staining and were used for analyses of those markers in brain 3.5 months non- $\operatorname{Tg} \mathrm{n}=5, \operatorname{Tg} \mathrm{n}$ $=3 ; 5$ months: non- $\operatorname{Tg} n=4, \operatorname{Tg} n=4 ; 7$ months: non- $\operatorname{Tg} n=5, \operatorname{Tg} n=5 ; 12$ months: non$\operatorname{Tg} n=6, \operatorname{Tg} n=4$. Data was analyzed across genotypes and age with two-way analysis of variance (ANOVA). Sidak's multiple comparisons test was used for post hoc comparisons within each age. 
A

B

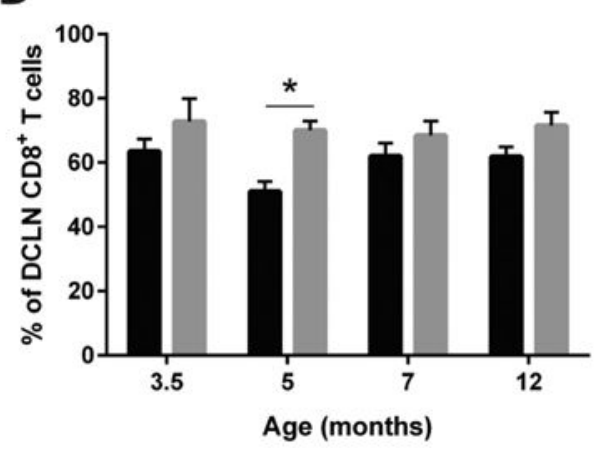

Fig. 2.
$\mathrm{CD4}^{+}$Effector T cells

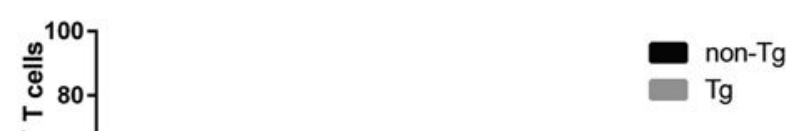

Altered naïve and effector $T$ cell populations in deep cervical lymph nodes of 5xFAD mice. While there are no significant differences in DCLN in the number of CD4 ${ }^{+}$or $\mathrm{CD}^{+} \mathrm{T}$ cells (data not shown), there are significant changes within the $\mathrm{CD}^{+}$and $\mathrm{CD} 8^{+} \mathrm{T}$ cell populations. A) $\mathrm{Tg}$ mice show increased frequency of $\mathrm{CD}^{+}$naïve $\mathrm{T}$ cells, and decreased frequency of $\mathrm{CD}^{+}$effector $\mathrm{T}$ cells, significant difference at 5 months. DCLN CD $4^{+} \mathrm{T}$ cell subsets shift, with age, towards memory phenotypes. Frequency of both central and effector memory $\mathrm{CD}^{+} \mathrm{T}$ cells subsets are significantly increased at 12 months from 3.5, 5 and 7 months, significant effect of age, no effect of genotype (data not shown). B) Tg mice show increased frequency of $\mathrm{CD}^{+}$naïve $\mathrm{T}$ cells, and decreased frequency of $\mathrm{CD} 8^{+}$Effector $\mathrm{T}$ cells, significant difference at 5 months. DCLN CD8 ${ }^{+} \mathrm{T}$ cell subsets shift, with age, towards memory phenotypes. Frequency of central memory $\mathrm{CD}^{+} \mathrm{T}$ cells are significantly increased at 12 months from 3.5, 5 and 7 months, significant effect of age, no effect of genotype (data not shown). Frequency of effector memory $\mathrm{CD}^{+} \mathrm{T}$ cells are significantly increased in non$\mathrm{Tg}$ mice as compared to Tg mice at 12 months of age, significant effect of age and of genotype (data not shown). 3.5 months: non- $\operatorname{Tg} \mathrm{n}=8, \mathrm{Tg} \mathrm{n}=9 ; 5$ months: non- $\mathrm{Tg} \mathrm{n}=11, \mathrm{Tg}$ $\mathrm{n}=11 ; 7$ months: non- $\operatorname{Tg} \mathrm{n}=11, \operatorname{Tg} \mathrm{n}=13 ; 12$ months: non- $\operatorname{Tg} \mathrm{n}=10, \operatorname{Tg} \mathrm{n}=9$. Within these groups a subset of samples had reliable CD44 and CD62L staining and were used for analyses of those markers in DCLNs: 3.5 months non- $\operatorname{Tg} n=5, \operatorname{Tg} n=3 ; 5$ months: non- $\mathrm{Tg}$ $\mathrm{n}=4$, $\operatorname{Tg} \mathrm{n}=4 ; 7$ months: non-Tg $\mathrm{n}=5$, $\operatorname{Tg} \mathrm{n}=5 ; 12$ months: non- $\mathrm{Tg} \mathrm{n}=6$, $\operatorname{Tg} \mathrm{n}=4$ Data was analyzed across genotypes and age with two-way analysis of variance (ANOVA). Sidak's multiple comparisons test was used for post hoc comparisons within each age. 


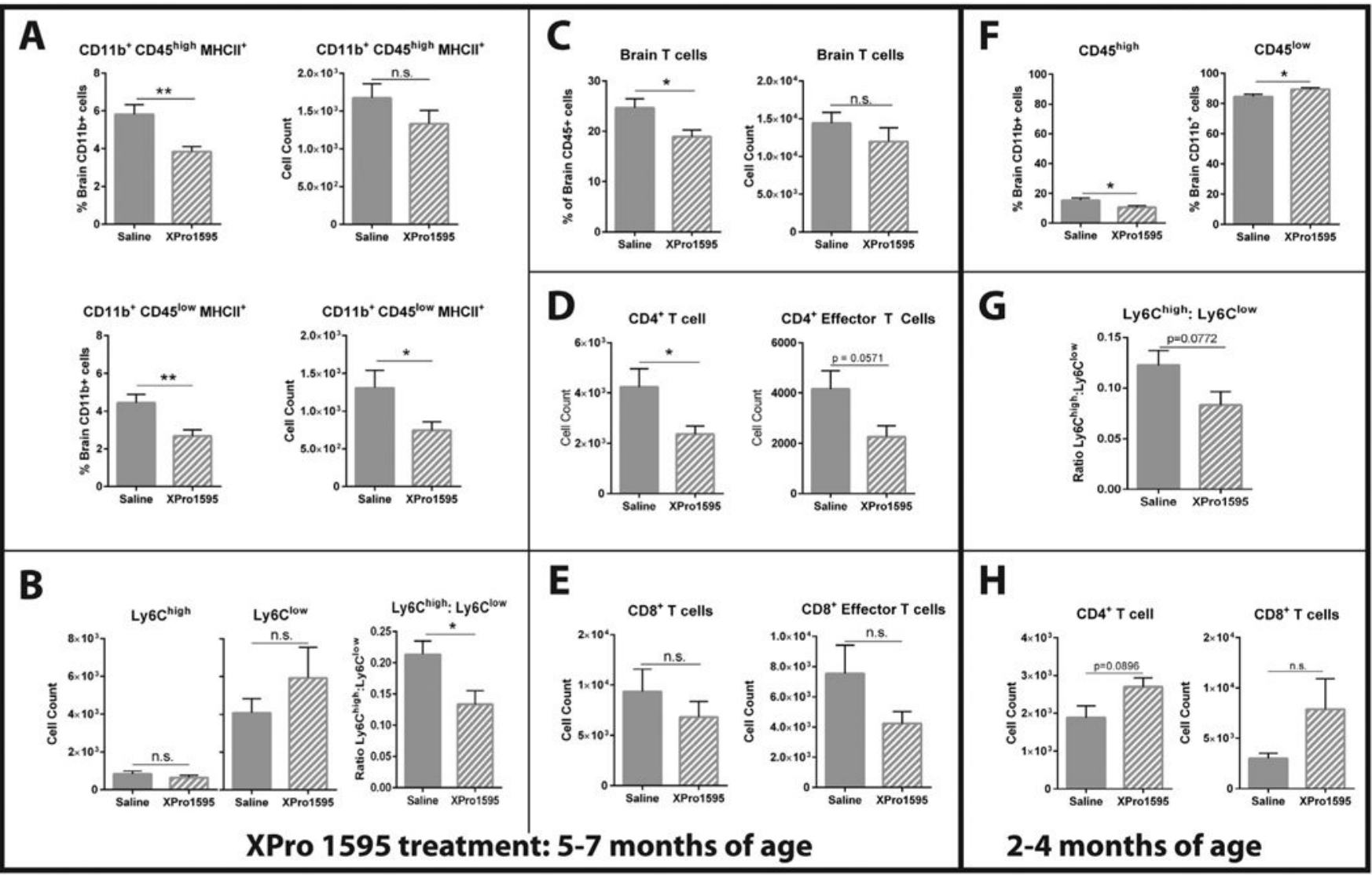

Fig. 3.

Inhibition of soluble TNF with XPro1595 decreases populations of activated CD11b ${ }^{+}$ immune cells and $\mathrm{CD} 4^{+} \mathrm{T}$ cells in the brain of $5 \mathrm{xFAD}$ mice. $\mathrm{Tg}$ and non- $\mathrm{Tg}$ mice were treated with XPro1595 (10 mg/kg s.c.) twice weekly for two months either from 5 to 7 months of age (A-E) or 2-4 months of age $(\mathrm{F}-\mathrm{H})$. A) Inhibition of soluble TNF with XPro1595 decreased $\mathrm{MHCII}^{+}$populations within both activated $\left(\mathrm{CD} 11 \mathrm{~b}^{+} \mathrm{CD} 45^{\text {high}}\right.$; frequency but not number) and quiescent (CD11b ${ }^{+} \mathrm{CD} 45^{\text {low }}$; frequency and number) immune cell populations, $* * \mathrm{p}<0.01 ; * \mathrm{p}<0.05$. B) Ly6C, a marker of peripheral monocytes, displayed alterations with inhibition of soluble TNF. The ratio of Ly6C ${ }^{\text {high }}:$ Ly6C ${ }^{\text {low }} \mathrm{CD} 11 b^{+}$brain immune cells in Tg mice is decreased, $* \mathrm{p}<0.05$. C) Brain $\mathrm{T}$ cells are decreased in frequency, but not number, with inhibition of soluble TNF, * $\mathrm{p}<$ 0.05. D) Within the $\mathrm{T}$ cell population the number of $\mathrm{CD}^{+} \mathrm{T}$ cells is decreased with inhibition of soluble TNF with a trend towards decreased $\mathrm{CD}^{+}{ }^{+}$effector T cells, ${ }^{*} \mathrm{p}<0.05$. E) There are no effects of soluble TNF inhibition on the $\mathrm{CD}^{+} \mathrm{T}$ cell population. $\mathrm{F}$ ) Inhibition of soluble TNF from 2 to 4 months of age decreased the activated (CD45 ${ }^{\text {high }}$ ) population and increased the quiescent $\left(\mathrm{CD} 45^{\text {low }}\right)$ population, $* \mathrm{p}<0.05$. G) There is a trend towards a decreased ratio of Ly6C ${ }^{\text {high }}:$ Ly $6 \mathrm{C}^{\text {low }} \mathrm{CD} 11 \mathrm{~b}^{+}$brain immune cells in $\mathrm{Tg}$ mice dosed from 2 to 4 months. H) No significant effects are seen in T cell populations at this age. Statistical analysis: significance was determined across treatment using non-parametric $t$ test. 


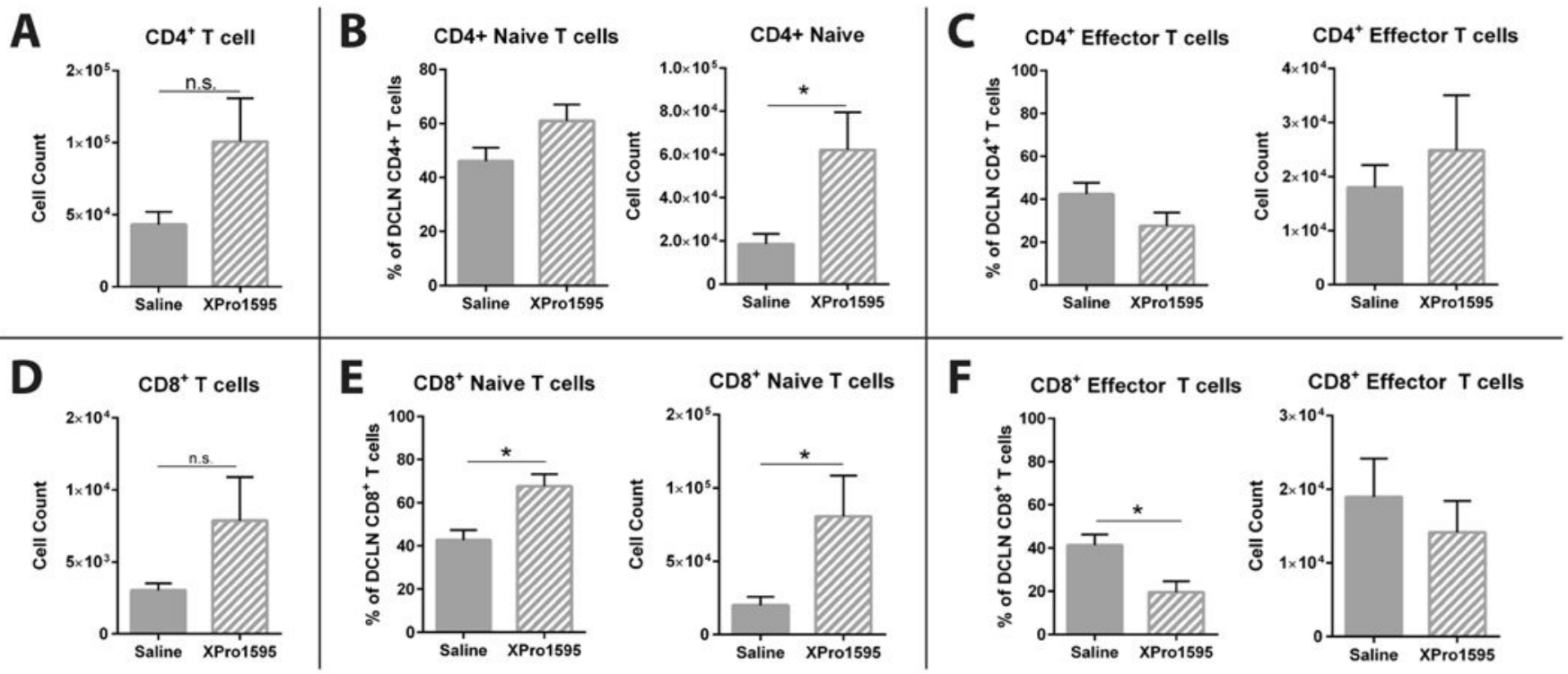

XPro 1595 treatment: 5-7 months of age

Fig. 4.

Inhibition of soluble TNF with XPro1595 increases the naïve T cell population in the deep cervical lymph nodes (DCLNs) of 5xFAD mice. There is no significant difference in the frequency or number of $\mathrm{CD}^{+}$(D) or $\mathrm{CD}^{+}$(A) $\mathrm{T}$ cells with in the DCLC following XPro1595 or saline treatment within genotype. B) Within the $\mathrm{CD} 4^{+} \mathrm{T}$ cell niche, the number but not frequency of naïve $\mathrm{T}$ cells is increased in $\mathrm{Tg}$ mice following inhibition of soluble TNF with XPro1595 as compared to saline treated Tg mice, $* p<0.05$. C) The frequency of $\mathrm{CD}^{+}$effector $\mathrm{T}$ cells is unchanged in Tg mice following inhibition of soluble TNF with XPro1595 as compared to saline-treated Tg mice. No effects are seen on population cell counts or within the $\mathrm{CD} 4^{+}$central memory or effector memory populations. E) Within the $\mathrm{CD} 8^{+} \mathrm{T}$ cell niche, the frequency and count of naïve $\mathrm{T}$ cells is increased in $\mathrm{Tg}$ mice following inhibition of soluble TNF with XPro1595 as compared to saline treated Tg mice, * $\mathrm{p}<0.05$. F) The frequency but not count of effector $\mathrm{T}$ cells is decreased in $\mathrm{Tg}$ mice following inhibition of soluble TNF with XPro1595 as compared to saline treated Tg mice, * $\mathrm{p}<0.05$. No effects are seen on population cell counts or on the $\mathrm{CD} 8^{+}$central memory populations. Statistical analysis: significance was determined across treatment using nonparametric $t$-test 


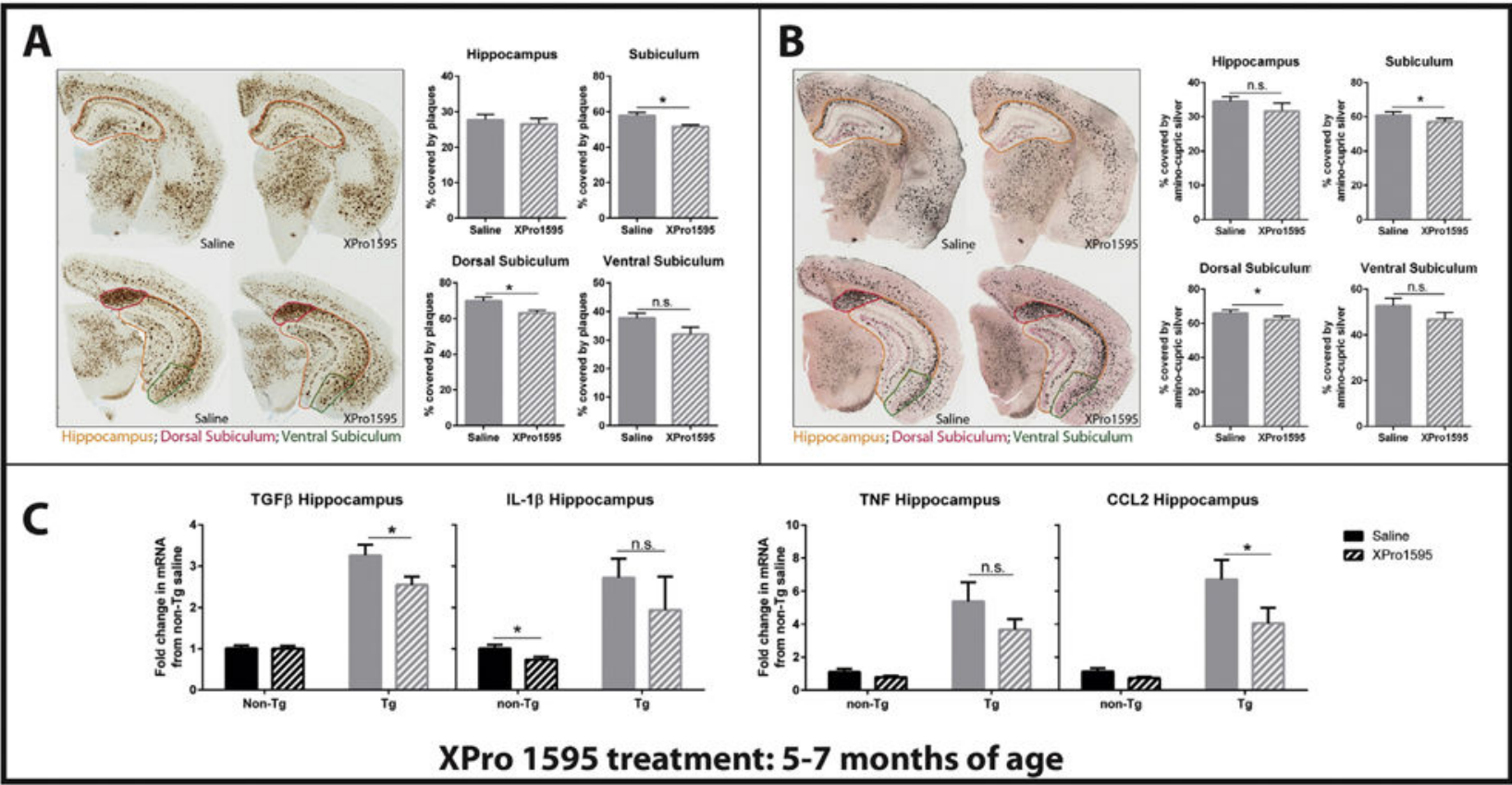

Fig. 5.

Inhibition of soluble TNF with XPro1595 decreases amyloid beta in the subiculum and decreases pro-inflammatory mRNA in the hippocampus of 5xFAD mice. Amyloid- $\beta$ (6E10) (A) and disintegration of multiple neuronal elements (measured by amino-cupric silver staining, NeuroScience Associates) (B) density was calculated in the hippocampus (yellow) and subiculum (dorsal: magenta; and ventral: green; posterior (when dorsal and ventral join): not shown) in saline- and XPro1595-treated Tg animals. A) No effect of soluble TNF inhibition was detected in the hippocampus; however, within the subiculum there was a significant reduction in amyloid burden specifically within the dorsal subiculum, $* \mathrm{p}<0.5$ B) No significant effects for soluble TNF inhibition were detectable by amino-cupric sliver staining in either hippocampus or subiculum. C) Inhibition of soluble TNF decreases the expression of pro-inflammatory genes in Tg and non-Tg mice. CCL2 and TFG $\beta$ are significantly decreased in Tg mice, ${ }^{*} \mathrm{p}<0.05$. Statistical analysis: IHC data significance was determined across treatment using non-parametric $t$-test. qPCR mRNA data was normalized to non-tg saline and analyzed across genotypes and drug treatment conditions with two-way analysis of variance (ANOVA). Sidak's multiple comparisons test was used for post hoc comparisons within genotype. 

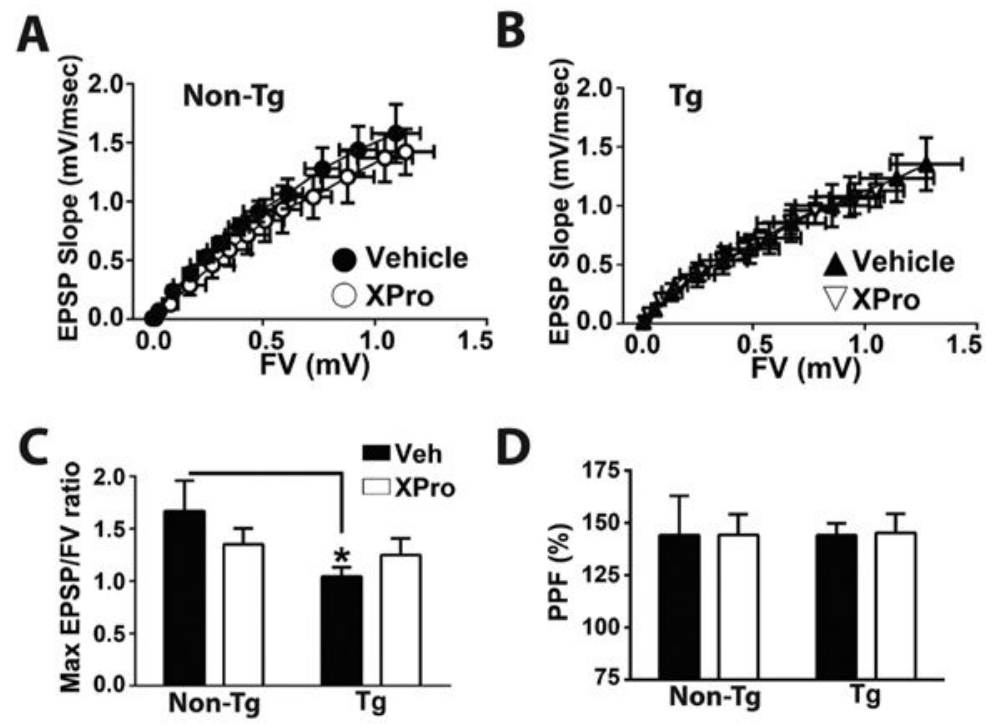

D

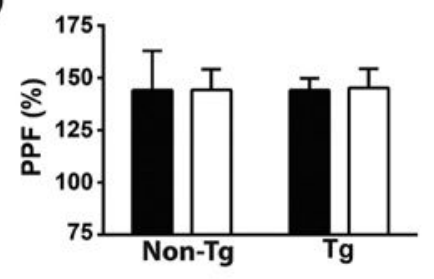

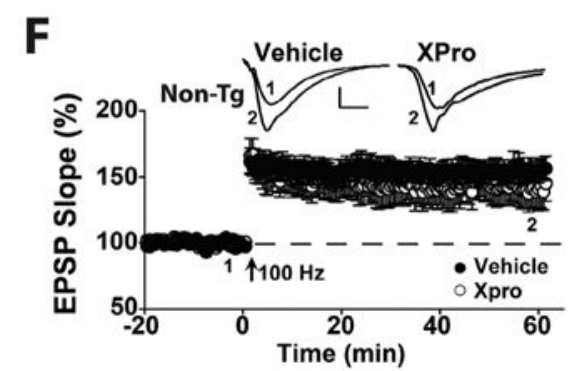

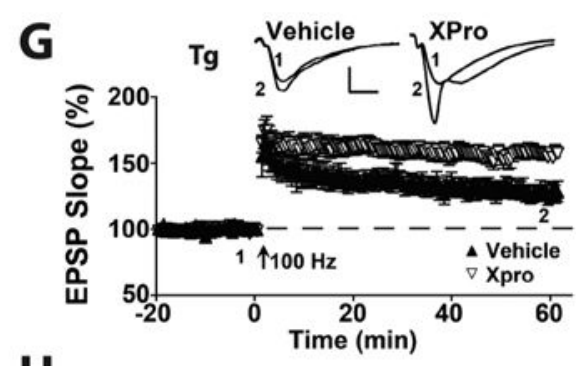

H

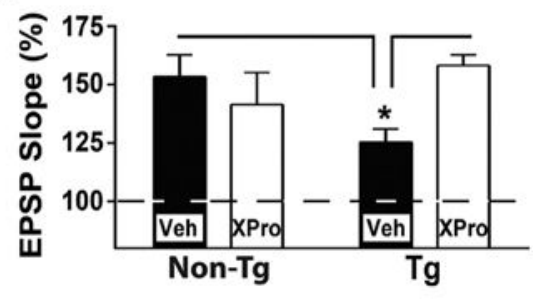

Fig. 6.

Inhibition of soluble TNF with peripheral XPro1595 administration in vivo rescued LTP impairment in 5xFAD mice. To determine if peripheral administration of XPro1595 modulates synaptic function in $\mathrm{Tg}$ mice, brain slices were harvested for analysis of CA3CA1 synaptic strength curves (A (non-Tg); B (Tg)) and LTP levels (F (non-Tg); G (Tg)). At four months of age, basal synaptic strength deficits were relatively mild in saline-treated $\mathrm{Tg}$ mice, characterized by a modest downward shift in the synaptic strength curve and a significant reduction $(\mathrm{p}<0.05)$ in the maximal EPSP/FV ratio, relative to non-Tg vehicletreated mice (C). XPro1595 had minimal effect on synaptic strength (A (non-Tg); B (Tg)), but it did slightly reduce and slightly increase the maximal EPSP/FV ratio in non-Tg and $\mathrm{Tg}$ mice, respectively (C). No genotype or XPro1595 treatment effects were observed for PPF measures (D) or population spike threshold (E). XPro1595 had more favorable effects for LTP deficits in Tg mice. LTP was induced in area CA1 using two $100 \mathrm{~Hz}$ stimulus trains (one second duration) separated by $10 \mathrm{~s}$. Relative to vehicle-treated non- $\mathrm{Tg}$ mice, the $\mathrm{Tg}$ group showed a significant reduction in LTP levels $(153.3 \pm 9.5 \%$ vs $125.3 \pm 5.7 \%, \mathrm{p}<$ $0.05)$ that was prevented by in vivo treatment with XPro1595 $(158.2 \pm 5.1 \%, \mathrm{p}<0.05$ vs $5 \mathrm{XFAD}$ vehicle group). In contrast, XPro1595 had minimal effect on LTP in non-Tg mice $(141.4 \pm 15.7 \%, \mathrm{H})$. Together, the results demonstrate that XPro1595 protects against LTP deficits in Tg mice. Synaptic strength parameters and LTP values were compared across genotypes and drug treatment conditions with two-way analysis of variance (ANOVA), Fisher's PLSD was used for post hoc comparisons. 

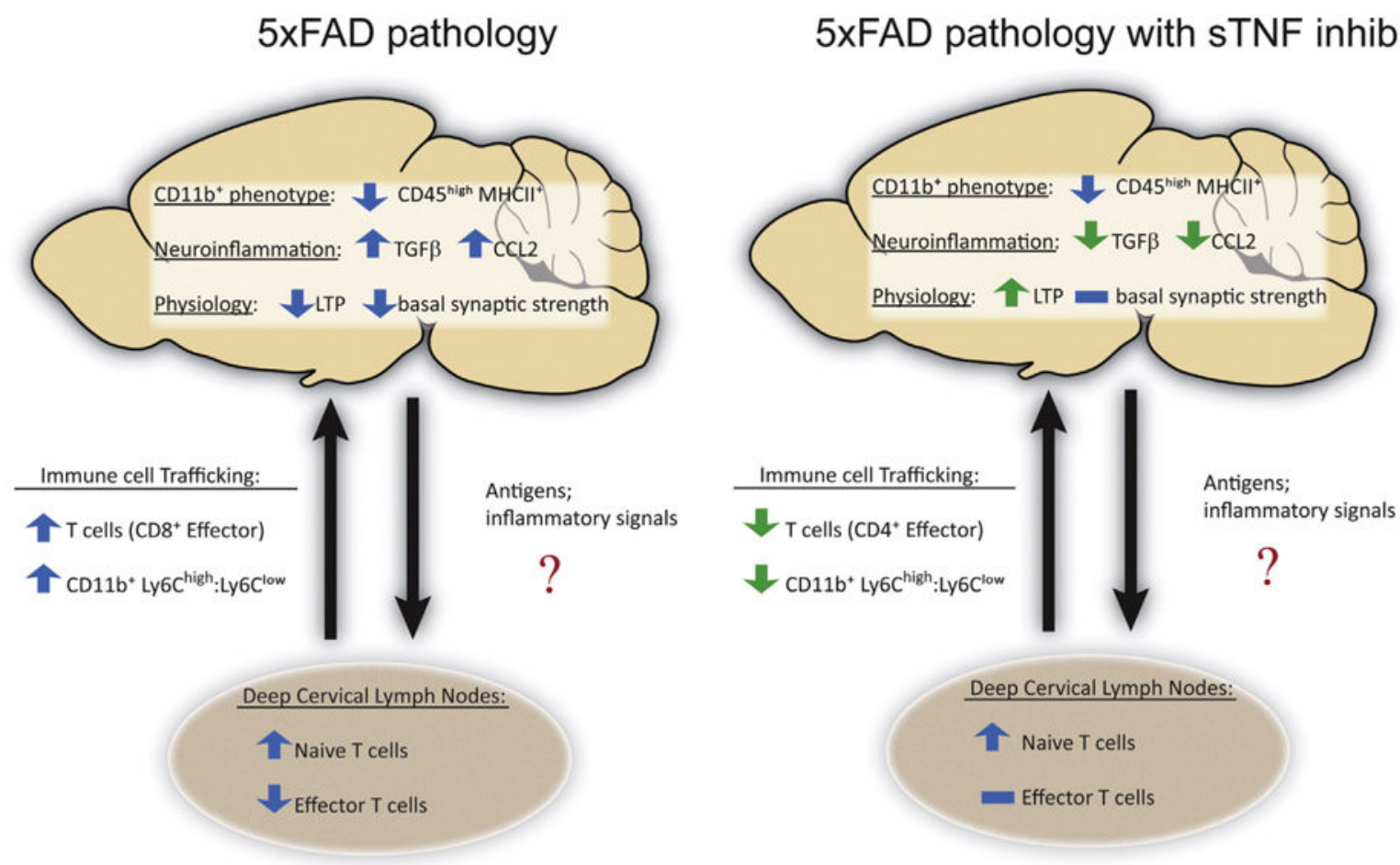

Fig. 7.

Specific targeting of sTNF/TNFR1 signaling rescues AD-like synaptic deficits and modulates AD-like associated immune cell population alterations. As Tg mice age, the brain becomes an inflamed environment with altered regulation of immune cell activation and peripheral immune cell trafficking to the CNS. While no evidence of peripheral inflammation is evident in plasma, there is evidence of altered $\mathrm{T}$ cell retention in the deep cervical lymph nodes to Tg mice, suggesting that the pro-inflammatory environment or potentially increased antigen presence is modulating peripheral immune cell populations. In vivo administration of peripheral XPro1595 to neutralize sTNF rescues LTP deficits and decreases amyloid (6e10) reactivity in the brain. These effects are associated with alterations in the brain inflammatory environment and immune cell traffic to the brain. In addition, XPro1595-treated group show further decrease in populations of activated CD11 $\mathrm{b}^{+}$immune cells as well as a decrease in $\mathrm{CD} 4^{+} \mathrm{T}$ cells suggesting these may be adaptive immune responses to the ongoing $\mathrm{AD}$-like pathology. 


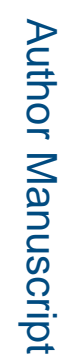

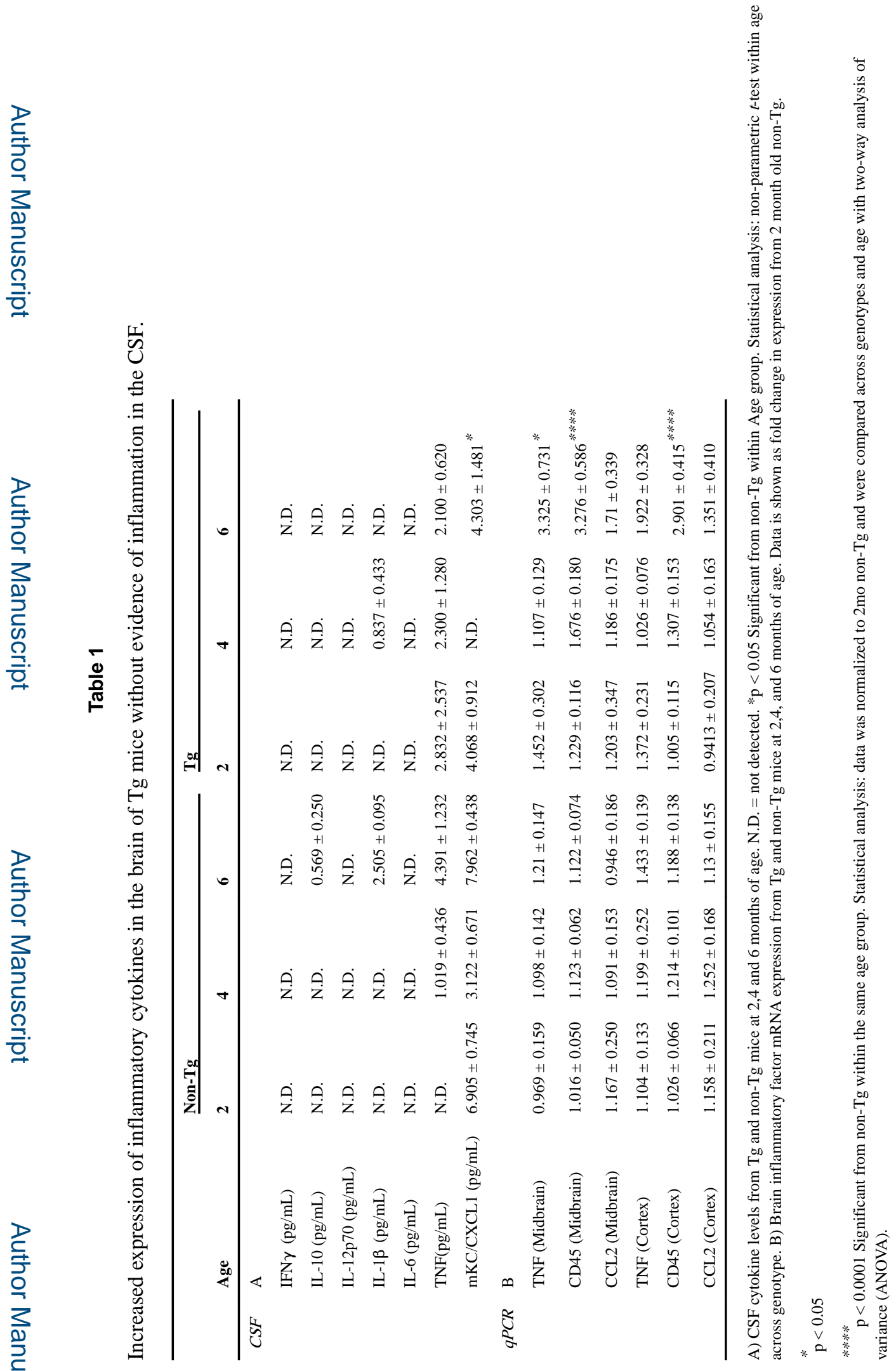

Neurobiol Dis. Author manuscript; available in PMC 2018 June 01. 


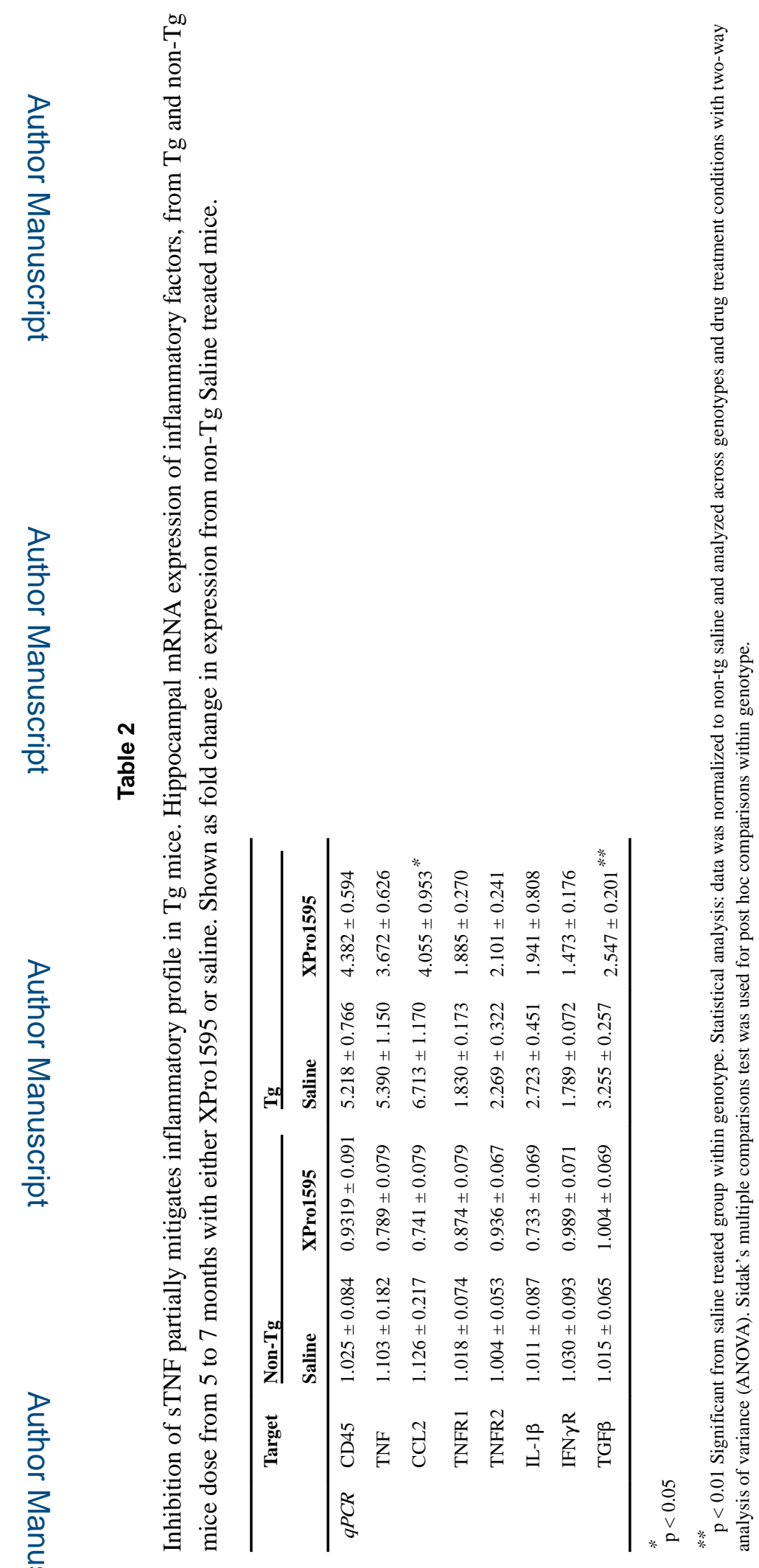

Neurobiol Dis. Author manuscript; available in PMC 2018 June 01. 